\title{
Transcriptome-Wide Mapping of Pea Seed Ageing Reveals a Pivotal Role for Genes Related to Oxidative Stress and Programmed Cell Death
}

\author{
Hongying Chen ${ }^{1,29}$, Daniel Osuna ${ }^{39}$, Louise Colville ${ }^{2 *}$, Oscar Lorenzo ${ }^{3}$, Kai Graeber ${ }^{4,5}$, Helge Küster ${ }^{5}$, \\ Gerhard Leubner-Metzger ${ }^{4 \ltimes a}$, Ilse Kranner ${ }^{2 \times b}$
}

1 Plant Germplasm and Genomics Center, Germplasm Bank of Wild Species, Kunming Institute of Botany, Chinese Academy of Sciences, Kunming, People's Republic of China, 2 Seed Conservation Department, Royal Botanic Gardens, Kew, Ardingly, West Sussex, United Kingdom, 3 Departamento de Fisiología Vegetal, Centro Hispano-Luso de Investigaciones Agrarias (CIALE), Facultad de Biología. Universidad de Salamanca, Salamanca, Spain, 4 Institute for Biology II, Botany/Plant Physiology, Faculty of Biology, Albert-Ludwigs-University Freiburg, Freiburg, Germany, 5 Institute for Plant Genetics, Unit IV - Plant Genomics, Leibniz Universität Hannover, Hannover, Germany

\begin{abstract}
Understanding of seed ageing, which leads to viability loss during storage, is vital for ex situ plant conservation and agriculture alike. Yet the potential for regulation at the transcriptional level has not been fully investigated. Here, we studied the relationship between seed viability, gene expression and glutathione redox status during artificial ageing of pea (Pisum sativum) seeds. Transcriptome-wide analysis using microarrays was complemented with qRT-PCR analysis of selected genes and a multilevel analysis of the antioxidant glutathione. Partial degradation of DNA and RNA occurred from the onset of artificial ageing at $60 \% \mathrm{RH}$ and $50^{\circ} \mathrm{C}$, and transcriptome profiling showed that the expression of genes associated with programmed cell death, oxidative stress and protein ubiquitination were altered prior to any sign of viability loss. After 25 days of ageing viability started to decline in conjunction with progressively oxidising cellular conditions, as indicated by a shift of the glutathione redox state towards more positive values ( $>-190 \mathrm{mV}$ ). The unravelling of the molecular basis of seed ageing revealed that transcriptome reprogramming is a key component of the ageing process, which influences the progression of programmed cell death and decline in antioxidant capacity that ultimately lead to seed viability loss.
\end{abstract}

Citation: Chen H, Osuna D, Colville L, Lorenzo O, Graeber K, et al. (2013) Transcriptome-Wide Mapping of Pea Seed Ageing Reveals a Pivotal Role for Genes Related to Oxidative Stress and Programmed Cell Death. PLoS ONE 8(10): e78471. doi:10.1371/journal.pone.0078471

Editor: Ken Mills, Queen's University Belfast, United Kingdom

Received June 19, 2013; Accepted September 13, 2013; Published October 29, 2013

Copyright: (c) 2013 Chen et al. This is an open-access article distributed under the terms of the Creative Commons Attribution License, which permits unrestricted use, distribution, and reproduction in any medium, provided the original author and source are credited.

Funding: This work was supported by the Spanish Ministerio de Educación y Ciencia and Junta de Castilla y León [BIO2011-26940, CSD200700057(TRANSPLANTA) and SA048A10-2 to O.L.], the German Research Foundation [DFGLe720/7 to G.L.M.], and the Chinese Academy of Sciences [KSCX2-EWJ-24 and Y3221411W1 to H.C.]. The Millennium Seed Bank Project is supported by the Millennium Commission, The Wellcome Trust, Orange Plc. and Defra. The Royal Botanic Gardens, Kew receive grant-in-aid from Defra. The funders had no role in study design, data collection and analysis, decision to publish, or preparation of the manuscript.

Competing Interests: The Millennium Seed Bank Project is supported by the Millennium Commission, The Wellcome Trust, Orange Plc and Defra. The authors confirm that the funding from Orange Plc does not alter their adherence to all of the PLOS ONE policies on sharing data and materials.

*E-mail: I.colville@kew.org

9 These authors contributed equally to this work.

wa Current address: School of Biological Sciences, Plant Molecular Science and Centre for Systems and Synthetic Biology, Royal Holloway, University of London, Egham, Surrey, United Kingdom

ab Current address: Institute of Botany, and Center of Molecular Biosciences, University of Innsbruck, Innsbruck, Austria

\section{Introduction}

The majority of seeds are orthodox (desiccation tolerant), and undergo dehydration during maturation prior to shedding. In the dry state metabolic activity is minimal, which limits the formation of reactive oxygen species (ROS) that cause oxidative damage associated with ageing, and enables seeds to survive for long periods. However, even in the dry state ROS formation as a result of auto-oxidative reactions leads to a gradual accumulation of oxidative damage to proteins, lipids and nucleic acids, and this eventually leads to viability loss $[1,2,3,4]$. The molecular basis of ageing has been more widely studied in animals than plants, revealing that ageing is orchestrated by signalling pathways and transcription factors [5]. However, the large-scale transcriptional changes related to seed ageing have not been investigated.
Seeds contain large amounts of stored mRNA, which in the case of Arabidopsis seeds represent more than half of all genes [6]. The stored mRNAs are translated into proteins during the early stages of imbibition [7]. Transcription has been reported to occur in dry seeds $[8,9,10]$, potentially facilitated by the existence of localised regions of higher water content. Studies of dormancy alleviation during dry after-ripening showed that whilst some transcripts increased in abundance, most declined [11]. This may reflect chemical reactions that are occurring in the dry seed rather than changes in gene expression. For example, nucleic acid oxidation occurs in seeds with moisture content (MC) as low as 4\%, and RNA is more prone to oxidation than DNA in part due to its single stranded structure. mRNA was found to be more sensitive to oxidation than total RNA, and oxidation was a targeted process, which would provide a means of modulating cell signaling during the early stages of imbibition $[11,12]$. 
Seed ageing is often studied using artificial ageing or controlled deterioration at higher relative humidity $(\mathrm{RH})$ and temperature to speed up the natural ageing process, so that seeds lose viability within days or weeks rather than decades [13]. In this study the transcriptional changes during the early stages of artificial ageing of garden pea (Pisum sativum) seeds at $50^{\circ} \mathrm{C}$ and $60 \% \mathrm{RH}$ were investigated using microarrays. This follows on from previous work on nucleic acid integrity [14], redox state [4] and volatile production [15] during the later stages of ageing when seed viability starts to decline. To address the problem of nucleic acid degradation during ageing, which accompanies viability loss [14], RNA integrity was assessed in incrementally deteriorated seed lots, and microarray analyses were conducted only with RNA of satisfactory quality from viable seeds at the initial stages of ageing (up to $15 \mathrm{~d}$ ). Quantitative real-time (qRT)-PCR analysis was conducted to monitor the expression of selected genes during the entire ageing time course (up to $55 \mathrm{~d}$ ). In addition, glutathione and other low molecular weight thiol-disulphide redox couples were measured to determine whether the cellular redox state could be related to transcriptional modulation during ageing. This work shows that transcriptional changes during ageing were accompanied by a progressive shift towards a more oxidising cellular environment and nucleic acid degradation, which occurred prior to any loss of seed viability. We propose that seed ageing is not only subject to chemical modification of cellular components but also to genetic control, and that programmed cell death (PCD) is initiated from the onset of ageing, which leads to viability loss.

\section{Materials and Methods}

\section{Seed material, ageing and germination treatments}

Seeds of garden pea (Pisum sativum L. cv Alaska Early; Abundant Life Seed Foundation, http://www.abundantlifeseeds.com) were equilibrated at $20^{\circ} \mathrm{C}$ and $60 \% \mathrm{RH}$ prior to ageing at $50^{\circ} \mathrm{C}$ and viability was assessed by germination testing [4]. For molecular analyses, 3-5 biological replicates of 20 pea seeds each were taken at each ageing interval, immediately frozen in liquid nitrogen, freeze dried and ground to a fine powder in a liquid nitrogencooled Teflon capsule using a laboratory ball mill (B. Braun Biotech International, http://www.bbraunbiotech.com). The powder was stored at $-70^{\circ} \mathrm{C}$ in humidity-proof vials.

\section{RNA and DNA extraction and assessment of integrity}

RNA was isolated from $30-50 \mathrm{mg}$ ground seed powder [16]. RNA quantity and integrity were tested using an Agilent 2100 Bioanalyzer (Agilent Technologies, http://www.agilent.com) together with an Agilent RNA 6000 Nano Labchip kit [17].

Genomic DNA was extracted from approximately $50 \mathrm{mg}$ freeze-dried seed powder [14]. DNA quality and quantity were assessed spectrophotometrically (Jasco, http://jasco.co.uk) at $260 \mathrm{~nm}$ and $280 \mathrm{~nm}$. Ten $\mu \mathrm{g}$ of DNA were separated on $1.5 \%$ agarose gel, and fragments visualized using a UV transilluminator (Syngene, http://syngene.com) after ethidium bromide staining. The intensities of $\sim 180$ bp fragments were quantified using image analysis software (Syngene). DNA laddering in the samples aged for $0,25,31$ and $55 \mathrm{~d}$ time points has been previously reported by Kranner et al. $[4,14]$. Here re-analysis of the same samples along with analysis of the early ageing time points $(8,10,12,13$ and $15 \mathrm{~d}$ ) was performed to show the entire ageing time course and to link the datasets together.

\section{HPLC analysis of low molecular weight thiol-disulphide redox state}

Five replicates of $50 \mathrm{mg}$ of ground seeds were analysed as described by Kranner and Grill [18] using a gradient, reversed phase HPLC (Jasco, http://www.jasco.co.uk) method with a C18 column (4.6 mm ID, $250 \mathrm{~mm}$ length; Kromatek, http://www. kromatek.co.uk). The half-cell reduction potentials ( $E_{\mathrm{LMW}}$ disulphide/2LMW thiol) were calculated using the Nernst equation [4,19], and the redox environment determined according to Schafer and Buettner [20].

\section{Determination of glutathione reductase and glucose-6- phosphate dehydrogenase activities}

Fifty $\mathrm{mg}$ ground material was extracted in $80 \%$ chilled acetone. For the measurement of glutathione reductase (GR) activity, glutathione disulphide (GSSG) and NADPH were added to the extract, and the oxidation of NADPH (extinction coefficient: $6.22 \mathrm{mM}^{-1} \mathrm{~cm}^{-1}$ ) was followed at $340 \mathrm{~nm}$ using a spectrophotometer (Jasco). The activity of glucose-6-phosphase dehydrogenase $(\mathrm{G} 6 \mathrm{PDH})$ was determined by following the reduction of $\mathrm{NADP}^{+}$at $340 \mathrm{~nm}$ after the addition of glucose-6-phosphate to the extract [21]. Data were expressed in nkat where one katal is defined as the amount of enzyme that catalyses the oxidation of $1 \mathrm{~mol} \mathrm{NADPH} \mathrm{s}^{-1}$ (for GR) or the reduction of $1 \mathrm{~mol} \mathrm{NADP}^{+} \mathrm{s}^{-1}$ (for G6PDH).

\section{Microarray analysis of gene expression}

For each biological replicate $(\mathrm{n}=3)$, one $\mu \mathrm{g}$ of total RNA was amplified and aminoallyl-labelled using a MessageAmp ${ }^{\mathrm{TM}}$ II aRNA Amplification kit (Ambion, http://invitrogen.com), and $7.5 \mu \mathrm{g}$ of cRNA were labelled with either Cy3 or Cy5 Mono NHS Ester $\left(\mathrm{Cy}^{\mathrm{TM}}\right.$ Dye Post-labelling Reactive Dye Pack, GE Healthcare Life Sciences, http://www.gelifesciences.com). The samples were purified using Megaclear ${ }^{\mathrm{TM}}$ (Ambion) and Cy3 and Cy5 incorporation was measured using a NanoDrop spectrophotometer (Thermo Fisher Scientific, http://www.thermofisher.com). Labelled cRNA was fragmented using RNA Fragmentation Reagent (Ambion). The integrity and average size of total RNA, cRNA and fragmented cRNA were evaluated using a Bioanalyzer 2100 (Agilent Technologies, http://www.agilent.com). The average size of fragmented cRNAs was about 100 nucleotides. The probe was diluted to a final volume of $100 \mu \mathrm{l}$ with hybridization solution.

Ps6kOLI1 microarrays (ArrayExpress accession number AMEXP-142) contained 5,246 70-mer oligonucleotide probes representing 5,220 EST-clusters derived from 11,930 pea ESTs [22]. Each probe was represented by three replicate spots per microarray.

200 pmol of Cy5 and Cy3 aRNA fragmented probes were mixed with $20 \mu \mathrm{g}$ of PolyA RNA (Sigma-Aldrich, http://www. sigmaaldrich.com) and $20 \mu \mathrm{g}$ of yeast tRNA (Sigma-Aldrich) in a final volume of $90 \mu \mathrm{l}$ of hybridization buffer ( $50 \%$ formamide, $6 \mathrm{X}$ SSC, $0.5 \%$ SDS, $5 \mathrm{X}$ Denhardt's). The probe was denatured at $95^{\circ} \mathrm{C}$ for $5 \mathrm{~min}$ and applied to the slide using a LifterSlip (Thermo Fisher Scientific, http://thermofisher.com). Slide hybridization, washing, drying and image capture were performed as recommended by the manufacturers.

Background correction and normalization of expression data were performed using LIMMA [23,24] which is part of Bioconductor, an $\mathrm{R}$ language project [25]. The resulting logratios were print-tip loess normalized for each array [23]. To obtain similar distribution across arrays and to achieve consistency between arrays, log-ratio values were scaled using the 
median-absolute-value as scale estimator [23]. Linear model methods were used for determining differentially expressed genes. Each probe was tested for changes in expression across replicates by using an empirical Bayes moderated t-statistic [24]. $P$-values were corrected to control the false discovery rate (FDR) [26]. The expected FDR was found to be less than $5 \%$, or $10 \%$ where specified. Only reproducible expression values (present in at least two gene replicates and FDR $<0.05$ ) were considered and $\log _{2}$ ratios were averaged. The hierarchical cluster was calculated and drawn using the TIGR MeV (Multiarray experiment viewer, version 4.4) software [27].

Microarray data have been deposited in the NCBI's Gene Expression Omnibus (GEO) [28] and are accessible through GEO Series accession number GSE24864 (http://www.ncbi.nlm.nih. gov/geo/query/acc.cgi?acc = GSE24864).

\section{cDNA synthesis and quantitative real-time PCR analysis}

One $\mu \mathrm{g}$ of pea seed RNA was spiked with $100 \mathrm{ng}$ of human RNA as an artificial internal control template and subsequently reverse transcribed using the Transcriptor First Strand cDNA Synthesis Kit (Roche, http://roche-applied-science.com). Two $\mu \mathrm{l}$ of cDNA were subjected to qRT-PCR using a LightCycler 2.0 Instrument (Roche), according to the LightCycler FastStart DNA Master ${ }^{\text {Plus }}$ SYBR Green I instructions (Roche). Amplification of the human porphobilinogen deaminase $(P B G D)$ gene using $P B G D$ specific primers (Transcriptor First Strand cDNA Synthesis Kit, Roche) resulted in a $151 \mathrm{bp}$ amplicon that was used as a reference gene. The sequences of pea-specific primer pairs used for qRTPCR are given in Table S1. The following parameters were used for amplification: 1 cycle at $95^{\circ} \mathrm{C}$ for $10 \mathrm{~min}, 45$ amplification cycles at $95^{\circ} \mathrm{C}$ for $10 \mathrm{~s}, 60^{\circ} \mathrm{C}$ for $10 \mathrm{~s}$ and $72^{\circ} \mathrm{C}$ for $10 \mathrm{~s}$. The raw fluorescence data from each individual amplification reaction generated by the LightCycler software were used to calculate PCR efficiency $(E)$ and cycle threshold $(C t)$ values using PCR Miner (http://www.miner.ewindup.info/) as described by Zhao and Fernald [29]. The efficiency-corrected expression ratio of the target genes relative to the $P B G D$ reference gene was calculated using the following equation (modified after Pfaffl) [30]: Ratio = $E_{\text {target }}$ Control $-C t$ sample $/ E_{\text {reference }}$ Ct control $-C t$ sample

Five biological replicates were used for all qRT-PCR analyses. Statistical analysis was performed using GraphPad Prism 4.

\section{Results}

\section{Viability loss and nucleic acid degradation during pea seed ageing}

Pea seeds were subjected to artificial ageing ("ageing" at $12 \%$ $\mathrm{MC}$ and $50^{\circ} \mathrm{C}$ ) for up to $55 \mathrm{~d}$, and viability was assessed by germination testing. High viability was maintained [ $96 \%$ to $100 \%$ total germination (TG)] during the first 15 days of ageing, and subsequently declined to $2 \%$ TG after 55 d (Figure 1A). Nucleic acid degradation is a marker of seed ageing, and DNA and RNA integrity were assessed in ageing pea seeds. There was little DNA fragmentation in non-aged control seeds, but ageing resulted in the appearance of "DNA ladders", composed of bands of $\sim 180$ base pairs and multiples thereof (Figure 1B). Electropherograms of RNA showed the gradual disappearance of distinct $18 \mathrm{~S}$ and $25 \mathrm{~S}$ rRNA peaks, increasing baseline noise and a decrease in the RNA integrity number (RIN; Figure S1) during seed ageing; indicative of RNA degradation. The effects of ageing were clearly evident from the earliest time point $(8 \mathrm{~d})$, however, no loss of viability was observed until after $25 \mathrm{~d}$ of ageing, by which point RNA was almost completely degraded.
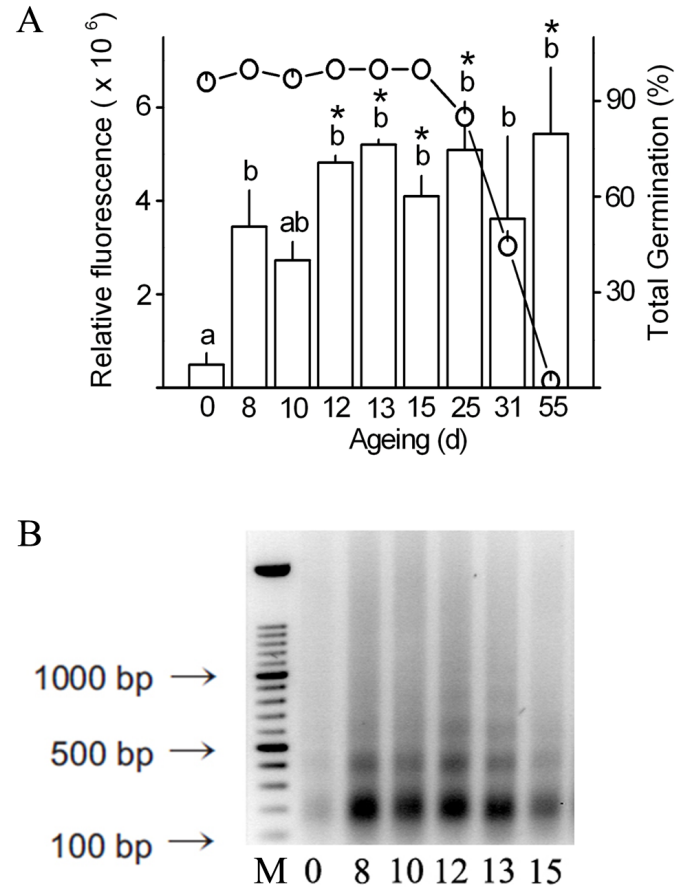

Figure 1. Fragmentation of DNA induced by ageing of pea seeds. (A) Semi-quantitative analysis of the $180 \mathrm{bp}$ DNA fragments by image analysis. White bars (left $y$-axis) represent the mean \pm SE relative fluorescence of the DNA fragments $(n \geq 3)$, and circles (right $y$-axis) represent total germination $(n \geq 3)$. Different letters indicate significant differences $(P<0.05)$ in DNA integrity across all ageing treatments and asterisks indicate significant differences $(P<0.01)$ between non-aged and aged seeds. (B) Gel electrophoresis of DNA from seeds. Lane ' $M$ ' shows a $100 \mathrm{bp}$ molecular mass marker (Roche) and the other lanes represent one of at least three independent biological replicates; the ageing period (in days) is shown at the bottom of each lane. doi:10.1371/journal.pone.0078471.g001

\section{Determination of low molecular weight thiol and disulphide concentrations and half-cell reduction} potentials and the activities of glutathione reductase and glucose-6-phosphate dehydrogenase

Accumulation of ROS and oxidative damage are key components of the ageing process [3,4]. Therefore, analysis of the oxidative status of $P$. sativum seeds during ageing was undertaken by measuring the changes in the concentration and redox state of low molecular weight thiols (cysteine, cysteinylglycine, $\gamma$-glutamylcysteine and glutathione; Figure 2). There were significant increases in the concentrations of cysteine and cystine from $15 \mathrm{~d}$ and $12 \mathrm{~d}$, respectively, which resulted in a significant shift in the half cell reduction potential of the cysteine/cystine redox couple ( $\left.E_{\text {cystine/2Cys }}\right)$ to more negative (more reducing) values after $15 \mathrm{~d}$ of ageing (Figure 2A). There were only slight changes in the concentrations of cysteinylglycine during ageing, whilst cystinylbis-glycine was increased from the onset of ageing. However, there was no signficant change in $E_{\text {Cys-bis-Gly/2Cys-Gly }}$ (Figure 2B). $\gamma$ Glutamylcysteine increased from the onset of ageing, before levels declined after $25 \mathrm{~d}$. In contrast, the concentration of bis- $\gamma$ glutamylcystine increased throughout the ageing period. $E_{\mathrm{bis}-\gamma \text {-Glu- }}$ Cys/2 $\gamma$-Glu-Cys was not significantly affected until after $25 \mathrm{~d}$ ageing, when it shifted towards more positive values (Figure 2C). The major low molecular weight thiol was glutathione and in non-aged seeds the concentration of total glutathione [reduced glutathione $(\mathrm{GSH})+$ glutathione disulphide $(\mathrm{GSSG})]$ was $1.9 \mu \mathrm{mol} \mathrm{g}^{-1} \mathrm{dry}$ 
weight, and comprised $11 \%$ GSSG. No significant change in GSH concentration occurred until $25 \mathrm{~d}$ when there was a 50\% drop in GSH concentration (Figure 2D). In contrast, the concentration of GSSG increased by $74 \%$ after $25 \mathrm{~d}$ ageing. After $55 \mathrm{~d}$ the total glutathione concentration was approximately half that of non-aged seeds, and 37\% comprised GSSG. $E_{\mathrm{GSSG} / 2 \mathrm{GSH}}$ did not change significantly during the first $15 \mathrm{~d}$ of ageing, but increased towards more positive (more oxidizing) values as seeds aged further $(25 \mathrm{~d}$, $31 \mathrm{~d}$ and $55 \mathrm{~d}$; Figure 2D). The overall thiol-defined redox environment was calculated by summing the products of the reduced thiol concentration and the corresponding half-cell reduction potential for each redox couple. In non-aged seeds the redox environment was $-6.15 \mathrm{mV} \mathrm{M}$ and this shifted to $-3.48 \mathrm{mV} \mathrm{M}$ after $8 \mathrm{~d}$ of ageing, and shifted further to $-1.64 \mathrm{mV} \mathrm{M}$ after $25 \mathrm{~d}$ of ageing when seeds started to lose viability. GSH/GSSG was the most abundant redox couple and therefore had the greatest influence on the redox environment, accounting for almost $94 \%$ in non-aged seeds. However, as GSH declined during ageing, the relative contribution of the other low molecular weight thiol-disulphide couples to the overall redox environment increased from $6 \%$ in non-aged seeds to $43 \%$ in seeds aged for $55 \mathrm{~d}$ (Figure 2E).

The activities of glucose-6-phosphate dehydrogenase (G6PDH) and glutathione reductase (GR) were measured to gain further insights into the relationship between oxidative stress and ageing. G6PDH activity was unaltered during ageing, whilst the activity of GR was lower in aged seeds $(P<0.05)$ compared with non-aged seeds at most ageing time points (Figure $2 \mathrm{~F}$ ).

\section{Global gene expression profiling during the early stages of seed ageing}

Microarray profiling of gene expression of non-aged control seeds and seeds aged for 8, 12 and 15 days was performed (Figures 3, 4, 5 and S2, and Tables S2-S4). A total of 717 differentially expressed genes were identified during the ageing process $\left[\geq 2\right.$-fold change in expression $\left(\log _{2}\right.$ ratio $\geq 1.0$ or $\leq-1.0$ ) with a false discovery rate $(\mathrm{FDR})<0.05]$, 330 of which were upregulated and 387 were down-regulated (Figure 3, S2 and Table $\mathrm{S} 2$ ). There was strong correlation between the gene expression profiles of the three ageing intervals (Figure S3). The most drastic changes in expression occurred after $15 \mathrm{~d}$ of ageing, with 140 and 115 genes specifically up-regulated and down-regulated, respectively (Figure 3). All 717 differentially regulated genes were clustered into 16 ageing-responsive expression patterns (Figures S2 and 4 and Table S3). The majority (68\%) of up-regulated genes belonged to clusters 8 and 15, whereas down-regulated genes belonged mainly to clusters 4 and 13. Clustered genes may be coregulated e.g. induced or repressed by the same transcription factors. Approximately half of the differentially expressed genes were assigned a functional annotation according to the euKaryotic Orthologous Groups (KOG) database, whilst 70\% and $40 \%$ of upregulated and down-regulated genes, respectively, were of unknown function. The annotated genes were divided into major functional categories according to the KOG classification (Figure 5, Table S2).

Up-regulated genes belonged to 21 functional KOG categories, whilst down-regulated genes were divided into 23 functional categories. At each ageing time point the majority of up- and down-regulated genes were associated with 'protein post-translational modification, turn-over and chaperones', and 'translation, ribosomal structure and biogenesis' (Figure 5). Many of the genes associated with 'post-translational modification, protein turnover and chaperones' encode proteins involved in the ubiquitinproteasome pathway. Also within this category were genes encoding proteins involved in redox modification of proteins, such as thioredoxin-h, peroxiredoxin, glutaredoxin and glutathione peroxidase and a number of heat shock proteins. Other genes within the 'cellular processes and signalling' class included several calcium signalling genes: two calmodulin genes and a calciumdependent protein kinase (CDPK) were repressed, whilst another CDPK was up-regulated. CDPKs are involved in stress response [31] and a CDPK protein was also up-regulated during artificial ageing of maize seeds [32].

The vast majority of genes associated with 'translation, ribosomal structure and biogenesis' encoded $40 \mathrm{~S}$ and $60 \mathrm{~S}$ ribosomal proteins, and around $75 \%$ were down-regulated during ageing (Tables S2 and S4). Rajjou et al. [33] also reported a decline in proteins involved in translation during seed ageing and suggested that this caused protein synthesis during germination to be delayed to allow repair of nucleic acid damage prior to translation. Other genes within the 'information storage and processing' class included genes involved in RNA processing and modification, of which two genes encoding aconitases, and an RNA helicase were induced by ageing. Nine chromatin structure genes, mainly encoding histone proteins, were also differentially expressed during ageing. Few genes involved in transcription or DNA replication and repair were ageing-responsive.

Twenty ageing-responsive genes were associated with 'carbohydrate transport and metabolism', of which nine encoded glycolytic enzymes, with five up-regulated during ageing (Table S2). Sucrose synthase was strongly up-regulated $\left(\log _{2}\right.$ ratio $\left.\geq 1.5\right)$ at early stages of ageing and hexokinase was also up-regulated. Two genes associated with 'energy production and conversion' were up-regulated during ageing: 12-oxophytodienoate reductase (OPR1), which is involved in jasmonic acid biosynthesis and also up-regulated during Arabidopsis leaf senescence [34], and dihydrolipoyl dehydrogenase. Other metabolic genes affected by ageing included genes associated with the transport and metabolism of lipids, amino acids, inorganic ions, coenzymes and nucleotides (Table S2). Two genes involved in control of the cell cycle and cell division were down-regulated during ageing and one gene encoding cullin-1 was up-regulated. Cullin-1 forms part of the SCF E3 ubiquitin ligase complex that mediates the ubiquitination of cell cycle proteins [35]. Patellin-5, which was the most strongly induced gene, is also involved in the cell cycle through membrane trafficking. Other strongly induced genes included glutathione-dependent formaldehyde dehydrogenase (FALDH), cysteine proteinase, two universal stress protein family genes and a legumin J precursor (Table S2). Legumins are seed storage proteins, and of seven seed-specific genes up-regulated during ageing, four encoded legumins (Table S4).

\section{Ageing-responsive expression of genes related to $P C D$ and oxidative stress}

Since DNA fragmentation, which is a hallmark of PCD, was observed from the earliest ageing time point ( $8 \mathrm{~d}$; Figure 1B), and oxidative stress has been linked with seed ageing [4], special attention was given to genes involved in PCD and oxidative stress response. A large proportion of differentially expressed genes were not KOG annotated, but many were assigned functional annotations according to the UniProt Knowledgebase, which enabled their inclusion in the functional categories shown in Table S4.

Twenty-three genes with predicted PCD-related functions showed differential expression during ageing, of these 15 were up-regulated, including Bax inhibitor 1 (BI-1), NIMA-related kinase, MA3-domain containing protein, two dehydration-responsive protein precursors $(R D 22)$, DNA-damage inducible protein 

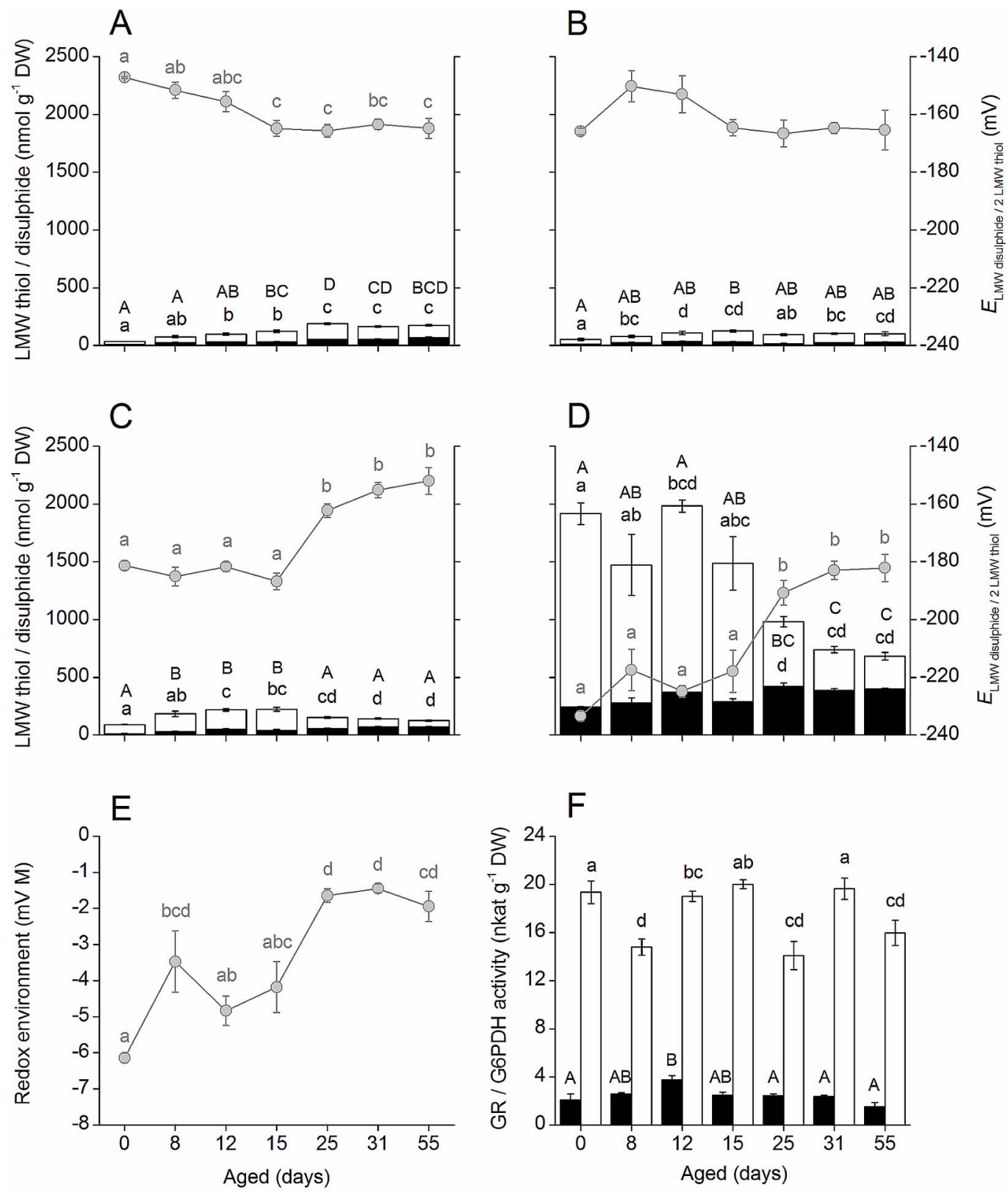

Figure 2. The effect of ageing on the redox state of low molecular weight thiol-disulphide couples and the activities of glutathione reductase (GR) and glucose-6-phosphate dehydrogenase (G6PDH). (A - D) Concentration of low molecular weight thiols (white bars; A: cysteine; B: cysteinyl-glycine; C: $\gamma$-glutamyl-cysteine; D: glutathione) and corresponding disulphides (black bars) at each ageing interval (left-hand yaxis). Bars represent means $\pm S E$. ( $(n=4$ or 5). Grey circles represent the half-cell reduction potential $\pm S E(n=4$ or 5$)$ of each redox couple (right-hand

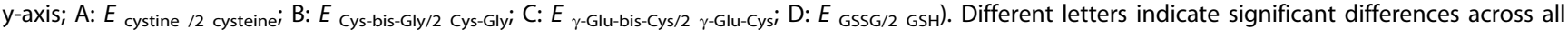
ageing time points (one-way ANOVA; Tukey's test, $P<0.05$; black upper case for thiols, black lower case for disulphides and grey lower case for halfcell reduction potentials). (E) Overall redox environment defined by the cysteine / cystine, cysteinyl-glycine / bis-cystinyl-glycine, $\gamma$-glutamyl-cysteine / $\gamma$-glutamyl-bis-cystine and GSH / GSSG redox couples represented by grey circles \pm SE $(n=4$ or 5). Different letters indicate significant differences (one-way ANOVA; Tukey's test, $P<0.05$ ) across all ageing time points. Ageing resulted in a shift of $E_{\mathrm{GSSG} / 2 \mathrm{GSH}}$, towards more positive values, indicating more oxidizing conditions; values more positive than $-180 \mathrm{mV}$ have previously been related to viability loss. (F) Activities of GR (white bars) and G6PDH (black bars). Bars represent means $\pm \mathrm{SE}(\mathrm{n}=4$ or 5). Different letters indicate significant differences (One-way ANOVA; Tukey's Test, $P<0.05$, lower case for GR and upper case for G6PDH) across all ageing time points. doi:10.1371/journal.pone.0078471.g002

(DDIl-like protein), knotted-like protein 4 (KNAT4), two cysteine proteinases (papain and RD21), aconitases, a putative sentrinspecific protease and dihydrolipoyl dehydrogenase (Table S4). All have been previously reported to be up-regulated during PCD triggered by various stresses e.g. ionizing radiation [36], apoptosis [37], and desiccation, salt and ABA treatments [38]. Half of the up-regulated PCD-related genes belonged to cluster 8, and were up-regulated only at the later ageing time point of $15 \mathrm{~d}$. All eight down-regulated genes were repressed by $8 \mathrm{~d}$ of ageing, and further repressed after $15 \mathrm{~d}$ of ageing, with half belonging to cluster 13 (Figure 4 and Table S3). 


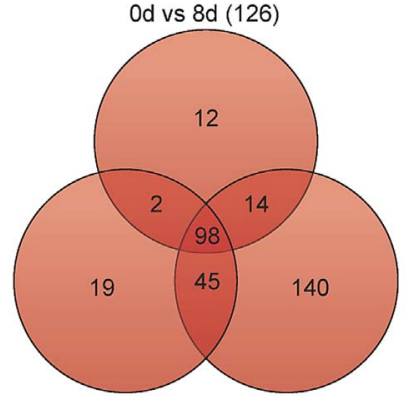

Od vs 12d (164) Od vs 15d (297)

Up-regulated genes ( $\geq 2$-fold)

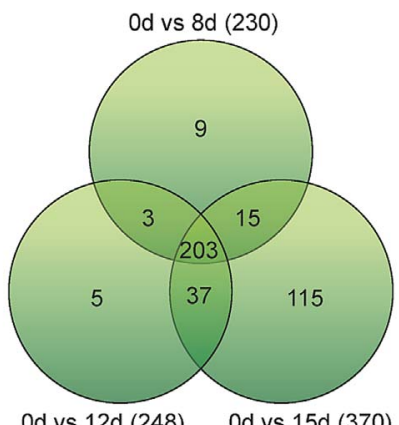

Od vs $12 \mathrm{~d}(248) \quad$ Od vs $15 \mathrm{~d}(370)$

Down-regulated genes ( $\geq 2$-fold)
Figure 3. Venn Diagrams showing the numbers of genes upand down- regulated during ageing of pea seeds. Values in brackets represent the total number of genes that are up- or downregulated ( $\geq 2$-fold change in expression compared to non-aged controls; $n=3)$ at a specific ageing time-point $(8 \mathrm{~d}, 12 \mathrm{~d}$, and $15 \mathrm{~d})$. doi:10.1371/journal.pone.0078471.g003

Ageing modulated the expression of 15 oxidative stressrelated genes (Table S4). Four genes were up-regulated, and encoded two FALDHs, a putative peroxidase and a thioredoxin $h$. FALDH exhibits S-nitrosoglutathione reductase activity, and may play a role in nitric oxide homeostasis [39]. Downregulated genes included peroxidase 42 , monodehydroascorbate reductase, glutathione peroxidase, glutathione-S-transferase and a glutaredoxin-related protein. Other genes that may be oxidative stress-responsive included two ferritin-3 genes, which were induced during seed ageing.

Twenty-eight ubiquitin-proteasome genes were affected by ageing, of which 11 genes were up-regulated. Most genes were induced within $8 \mathrm{~d}$ of ageing (cluster 3 and 15) and their expression increased with ageing period, indicating that these genes may play a role in activating ageing-responsive pathways. Four genes were induced only after $15 \mathrm{~d}$ of ageing (cluster 8), and may be involved in the ubiquitination of proteins for degradation as part of the execution phase of PCD (Table S4).

\section{Analysis of gene expression throughout the complete ageing time course by qRT-PCR using an artificial reference gene}

The assessment of gene expression during seed ageing is fraught with difficulties due to the degradation of nucleic acids, leading to an apparent down-regulation of overall gene expression levels, including housekeeping genes [40]. In addition, many commonly used housekeeping genes are not stably expressed in seeds [41]. Our microarray analysis showed that 21 commonly used housekeeping genes were differentially expressed during seed ageing (Table S4). To address this problem pea RNA was spiked with total human RNA and the human-specific porphobilinogen deaminase $(P B G D)$ gene was used as an artificial reference gene to normalize the expression of pea-specific target genes using qRTPCR (see Figure S4 for an overview) [42,43,44]. PBGD expression

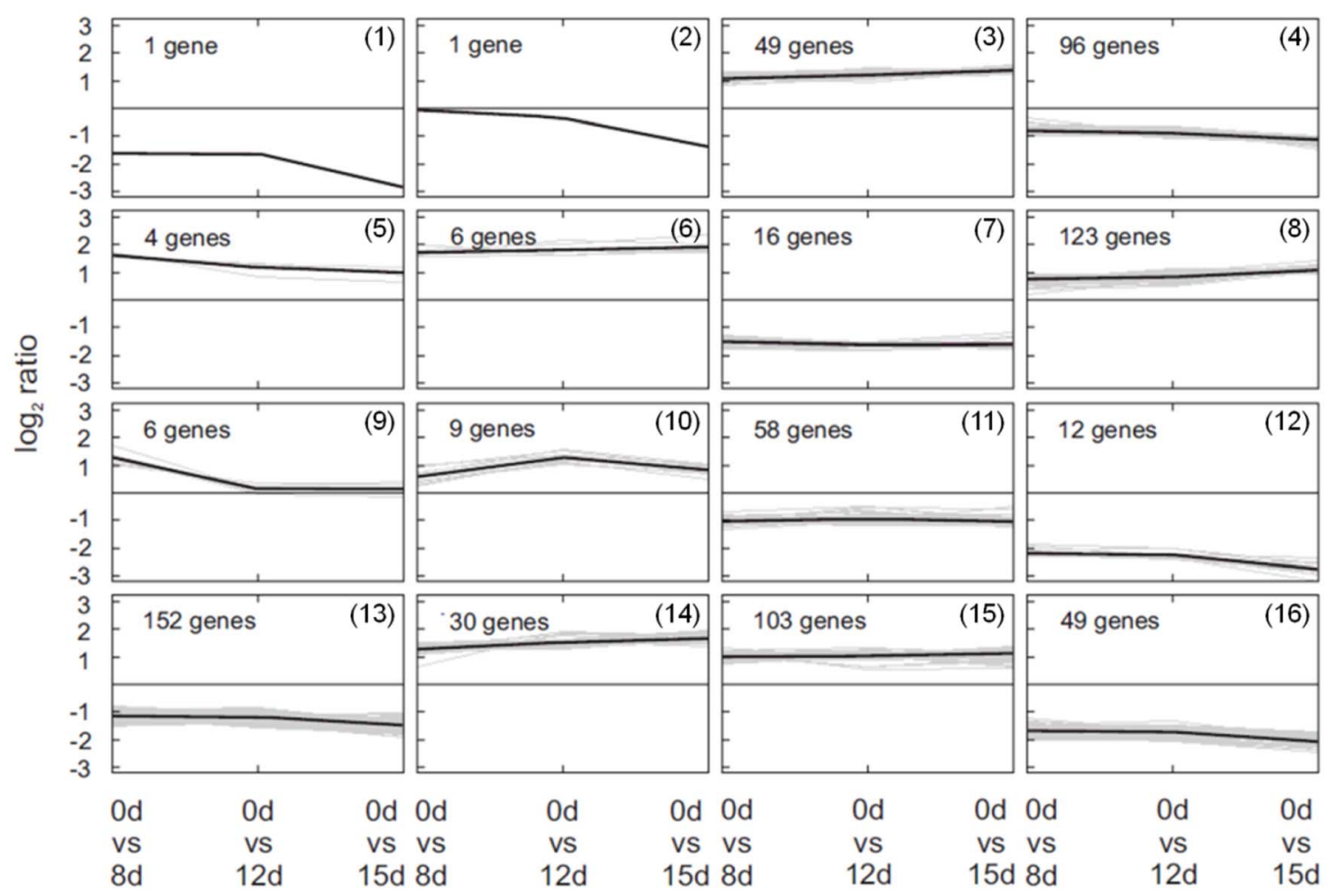

Figure 4. Expression profiles of ageing-responsive gene clusters. Genes that were differentially expressed ( $\geq 2$-fold change in expression compared to non-aged controls) at one or more time points ( $8 \mathrm{~d}, 12 \mathrm{~d}$ and $15 \mathrm{~d}$ ) during ageing of Pisum sativum seeds were clustered using TIGR Multi-experiment Viewer, version 4.4 [27]. Clustering was performed on the basis of similarities between gene expression profiles throughout the ageing time course. The mean expression values for each gene at each of the three ageing time points ( $8 \mathrm{~d}, 12 \mathrm{~d}$ and $15 \mathrm{~d}$ ) were normalized to the mean expression in the non-aged controls $(0 \mathrm{~d})$. log2 (ratio) was used to represent expression levels. Clusters 1 and 2 contain only one gene due to their unique expression profiles during the ageing process. Three biological replicates were used for each transcriptomic comparison. Values in brackets correspond to the cluster numbers used in the text and Table S3. doi:10.1371/journal.pone.0078471.g004 
A

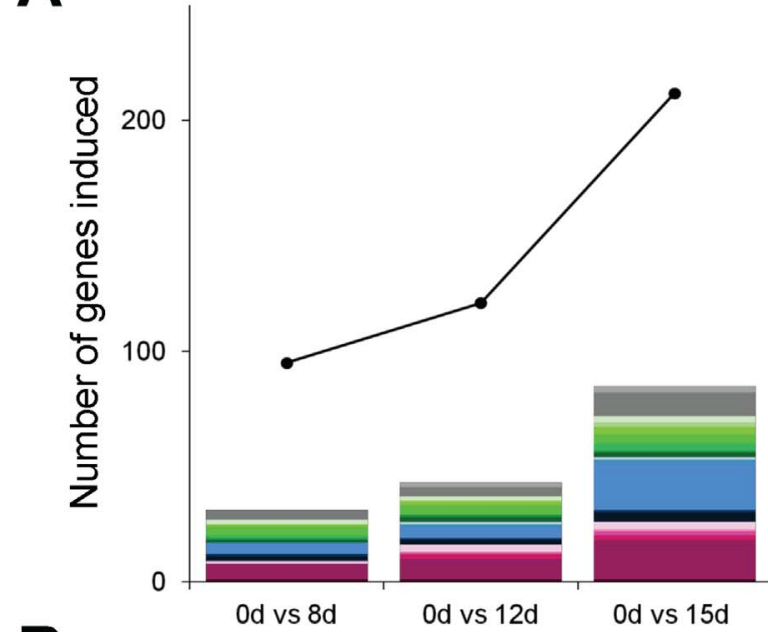

B

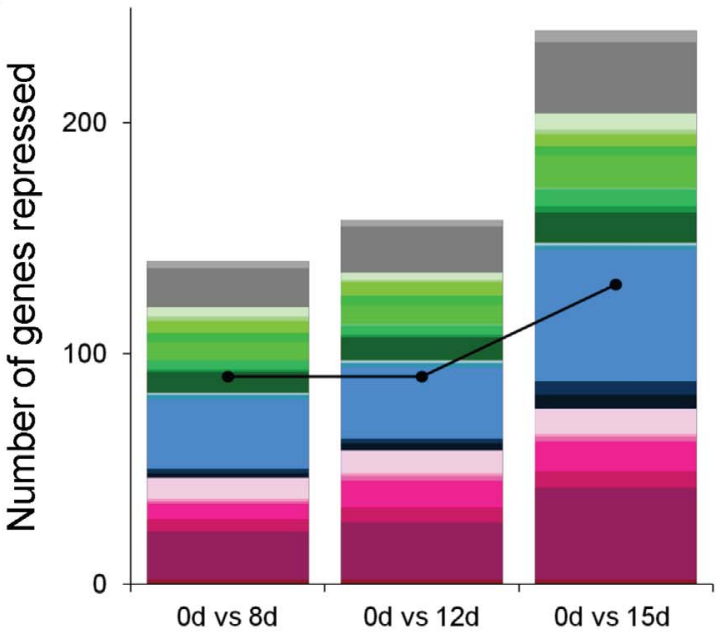

Function unknown

aunction unknown (S)

- General function prediction only (R)

Cellular processes and signalling

secondary metabolites biosynthesis, transport and catabolism (Q)

- Inorganic ion transport and metabolism (P)

- Lipid transport and metabolism (I)

= Coenzyme transport and metabolism $(\mathrm{H})$

- Carbohydrate transport and metabolism (G)

nucleotide transport and metabolism (F)

- Amino acid transport and metabolism (E)

- Cell cycle control, cell division and chromosome pairing (D)

- Energy production and conversion (C)

Information storage and processing

= DNA replication, recombination and repair $(\mathrm{L})$

- Transcription (K)

- Translation, ribosomal structure and biogenesis (J)

- Chromatin structure and dynamics (B)

- RNA processing and modification (A)

Metabolism

Cytoskeleton $(Z)$

Nuclear structure $(Y)$

Defense mechanisms (V)

- Intracellular trafficking, secretion and vesicular transport (U)

- Signal transduction mechanisms $(T)$

a Post-translational modification, protein turnover, chaperones $(O)$

- Cell wall/membrane/envelope biogenesis (M)

Figure 5. Numbers of genes up- and down-regulated during ageing of pea seeds according to KOG functional category. (A) Upregulated genes $\left(\log _{2}\right.$ ratio $\left.\geq 1.0\right)$; (B) down-regulated genes $\left(\log _{2}\right.$ ratio $\left.\leq-1.0\right)$. Stacked bars represent the numbers of genes induced or repressed after 8 days, 12 and 15 days of ageing $(n=3)$. Colours represent different KOG classes (grey, function unknown; green, cellular process and signaling; blue, information storage and processing; purple, metabolism) and the different shades correspond to the KOG functional categories within each class. The black circles and lines represent the numbers of induced or repressed genes that were not classified according to the KOG database. doi:10.1371/journal.pone.0078471.g005

was detected only in pea samples spiked with human RNA and there were no detectable signals for any of the target $P$. sativum genes when total human RNA was used exclusively as template, nor did the addition of total human RNA to the pea samples change the non-normalised expression of any of the target $P$. sativum genes compared to non-spiked samples.

The expression of two glutathione-related genes encoding glutathione reductase (GR) and glucose-6-phosphate dehydrogenase $(\mathrm{G} 6 \mathrm{PDH})$, two potentially PCD-related genes encoding voltage-dependent anion channel (VDAC) and adenine nucleotide translocator (ANT) and three commonly used house-keeping genes [actin $1(A c t)$, tubulin-beta-3 (Tub), elongation factor-1 alpha $(e F)$ ] in seed samples incrementally aged for up to 55 days were investigated using qRT-PCR. Linear regression analysis was used to determine stably expressed genes during ageing. The artificial $P B G D$ reference clearly displayed the smallest overall variation (Figure S5). G6PDH expression was unaltered during ageing, whilst GR, VDAC, ANT, Tub, Act, eF were all down-regulated (Figure 6; Figure S5). The down-regulation of house-keeping genes confirmed that the artificial $P B G D$ reference gene was a more appropriate normalisation factor. The expression patterns observed using qRT-PCR generally confirmed the microarray data, with the exception of $G R$, which was unaltered in the microarray analyses, and $A N T$, which was repressed from the earliest ageing time point in the microarray study, but not significantly repressed until 25 d ageing in the qRT-PCR analysis. For all genes analysed, with the exception of $G 6 P D H$, expression declined further at the later stages of ageing (after $25 \mathrm{~d}$ ), and was lowest in seeds aged for $55 \mathrm{~d}$, which is likely to reflect the widespread RNA degradation at these time points.

\section{Discussion}

An increase in glutathione half-cell reduction potential coincides with the onset of viability loss

$E_{\mathrm{GSSG} / 2 \mathrm{GSH}}$ is proposed to be a marker of cell viability $[4,20]$, and the dramatic increase in $E_{\mathrm{GSSG} / 2 \mathrm{GSH}}$ after $25 \mathrm{~d}$ ageing coincided with the onset of viability loss (Figure $1 \mathrm{~A}$ and 2D), as 

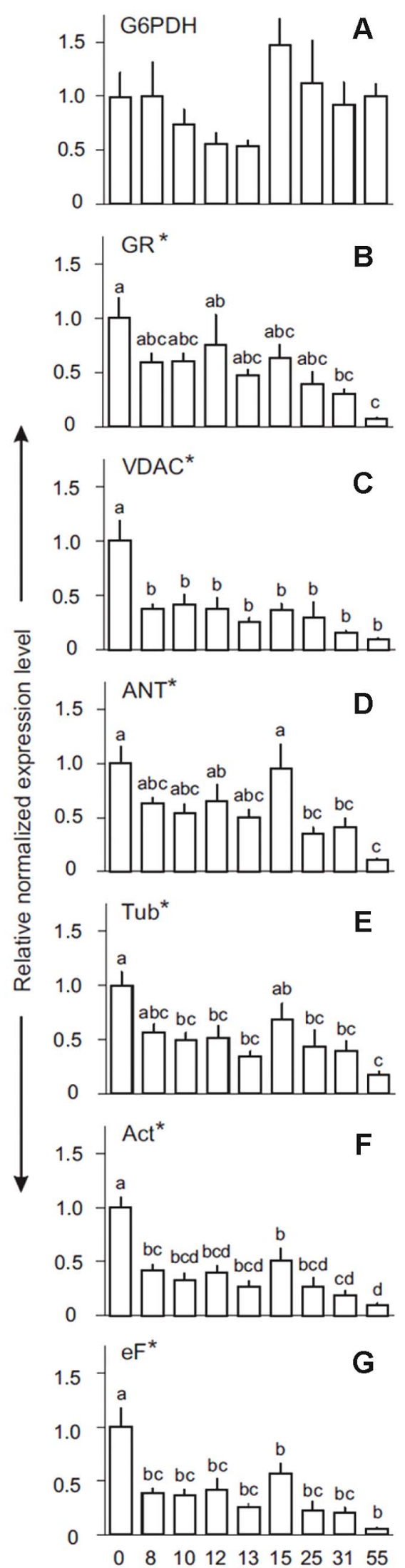

Ageing (d)

Figure 6. Normalised expression of selected genes during seed ageing. Expression of glucose-6-phosphate dehydrogenase (G6PDH), glutathione reductase $(G R)$, voltage-dependent anion channels (VDAC), adenine nucleotide translocator (ANT), $\beta$-Tubulin 3 (Tub), Actin 1 (Act) and elongation Factor-1 $\alpha(e F)$ was analysed using qRT-PCR. Data were normalised using the spiked human $P B G D$ gene and changes in expression following ageing are shown relative to the non-aged control. Bars represent means + SE $(n=5)$. Different letters indicate significant differences (one-way ANOVA; Tukey's test, $P<0.05$ ) across all ageing time points. Asterisks denote genes with a regression slope deviating significantly from zero (linear regression analysis, $P<0.05, R^{2}$ : $G 6 P D H=0.02610 ; G R=0.8296 ;$ VDAC $=0.5265 ; A N T=0.6664 ;$ Tub $=0.5899 ;$ Act $=0.5293 ;$ eF $=0.5565$ ). doi:10.1371/journal.pone.0078471.g006

previously reported by Kranner et al. [4], and is indicative of progressive oxidative stress during ageing. This work complements the earlier study [4], by analysing changes in half-cell reduction potentials of low molecular weight thiols throughout the ageing time course, including the early stages of ageing prior to the onset of viability loss, which were not previously reported. $E_{\mathrm{bis}-\gamma \text {-Glu-Cys/ }}$ $2 \gamma$-Glu-Cys followed a similar pattern to $E_{\mathrm{GSSG} / 2 \mathrm{GSH}}$, whilst neither $E_{\text {cystine/2Cys }}$ nor $E_{\text {Cys-bis-Gly/2Cys-Gly became more positive during }}$ ageing of pea seeds. Probit analysis was used to estimate that $50 \%$ of seeds lost viability when $E_{\mathrm{GSSG} / 2 \mathrm{GSH}}$ and $E_{\mathrm{bis}-\gamma \text {-Glu-Cys } / 2 \gamma-\text { Glu-Cys }}$ reached -187 to $-182 \mathrm{mV}$ and -159 to $-156 \mathrm{mV}$, respectively, which are similar to the values predicted for artificially aged Lathyrus pratensis seeds [19]. The low molecular weight thiol-defined cellular redox environment became more oxidising as ageing progressed, and $50 \%$ of seeds lost viability when the redox environment reached values of -1.45 to $-0.77 \mathrm{mV} \mathrm{M}$. A similar pattern was observed in artificially aged Lathyrus pratensis seeds, although the zone of viability loss was estimated to be narrower and slightly more positive $(-1.03$ to $-0.69 \mathrm{mV} \mathrm{M})$, which likely reflects inter-species variation in the dynamics of thiol-disulphide turn-over

The decline in GSH as ageing progressed could be due to degradation leading to the formation of cysteinylglycine and cysteine, both of which increased slightly during seed ageing, but not enough to account for the decline in GSH levels. An alternative fate for GSH is the $S$-glutathionylation of protein Cys residues, which occurs under conditions of oxidative stress and may serve to protect protein thiols from irreversible oxidation. $S$ Glutathionylation can directly influence the activity of proteins, and targets include glycolytic enzymes, signalling proteins and proteins involved in redox homeostasis [45]. S-Glutathionylation has also been reported to be an early event in the induction of cell death [46].

GR plays an important role in maintaining a high ratio of GSH/GSSG in cells $[47,48,49]$, and activity decreased during ageing. A similar response was observed following treatment with high concentrations of $\mathrm{H}_{2} \mathrm{O}_{2}$ [50], which suggests that ROS accumulation during ageing could cause reduction in GR activity, leading to a decreased GSH/GSSG ratio. PCD is associated with GSH/GSSG imbalance, and a rise in GSSG has been suggested to precede the loss of mitochondrial integrity, cytochrome c release and caspase- 3 activation [4,51]. Glutathione redox state has also been reported to influence the activity of the ubiquitin/26S protein degradation pathway [52], which was shown in this study to play an important role in ageing of pea seeds (Table S4), and previously noted to be involved in senescence [53].

\section{DNA laddering indicates the involvement of programmed cell death in seed ageing}

RNA degradation [54] and DNA fragmentation are associated with PCD, and although PCD may occur in the absence of both $[55,56]$; there are few reports of DNA laddering occurring under 
any circumstances apart from PCD [57]. Therefore, this indicates that PCD was initiated from the very beginning of ageing. The upregulation of $46 \%$ of differentially expressed genes indicates the occurrence of de novo transcription, so apparent changes in expression were not solely due to degradation of stored mRNAs. The moisture content of the pea seeds was $12 \%$, and at $50^{\circ} \mathrm{C}$ the cytoplasm, although highly viscous, is not in a glassy state, which would facilitate the occurrence of cellular processes including transcription. The decline in transcript abundance of 387 genes may result from transcriptional regulation, but degradation of stored mRNA may also contribute to the decline. The mechanisms of selective mRNA degradation have yet to be determined, but may depend on the inherent sensitivity of specific mRNAs to oxidation [12].

\section{A decline in antioxidant capacity may facilitate the progression of programmed cell death signalling}

The down-regulation of several antioxidant genes is possibly due to mRNA degradation, and a similar decline was reported for catalase transcript levels during ageing of sunflower seeds [58]. Expression of genes encoding antioxidants or proteins involved in repair of oxidative damage may be repressed as part of the PCD process, to allow cell death to proceed rapidly. He and Kermode [59] reported that $\mathrm{H}_{2} \mathrm{O}_{2}$ production was required for activation of caspase-like proteases, and that antioxidants slowed the progression of cell death. Furthermore, inhibition of the degradation of catalase by the ubiquitin-proteasome pathway also slowed cell death, suggesting that selective degradation of antioxidant enzymes provides a means of regulating ROS production and PCD. Nitric oxide and protein nitrosylation may play a role in PCD by modulating antioxidant activity [60]. Some oxidative stress-related genes were induced during seed ageing. For example ferritins, which bind iron and prevent ROS formation via the Fenton reaction [61], and thioredoxin $h$, which may be induced by oxidative stress [62], and is involved in the regulation of protein thiolation. The thioredoxin and glutaredoxin systems are reported to be involved in apoptosis-like PCD [63,64]. Reduced thioredoxin binds to apoptosis signal-regulating kinase 1 (ASK1) to inhibit downstream signalling pathways. Glutaredoxins and peroxiredoxins may also act in a similar way through interaction with the thioredoxin-binding domain of ASK1 [65,66]. Other negative regulators of ASK1 include 14-3-3 proteins [67]. Two genes encoding 14-3-3-like proteins were altered in expression during seed ageing, one was up-regulated and the other downregulated. ROS and oxidative stress cause dissociation of inhibitor proteins to activate ASK1 and initiate downstream MAP kinase signalling pathways leading to stress responses and PCD [68].

\section{Seed ageing causes endoplasmic reticulum stress}

PCD in animals and plants shares some common phenomena, such as the release of apoptogenic proteins (e.g. cytochrome c) from the mitochondria [69], induction of caspase-like proteases, and DNA cleavage by PCD-active nucleases to yield multimers of approximately 180bp [70,71]. In animal cells regulation of the mitochondrial PCD pathway involves proteins of the B-cell lymphoma 2 (Bcl-2) family e.g. Bax which induces release of cytochrome $\mathrm{c}$ from the mitochondria and $\mathrm{Bcl}-2$, which inhibits Bax. Neither protein has been identified in plants, although the heterologous expression of mammalian Bax in A. thaliana and tobacco causes PCD, which is reversed by the over expression of Bax inhibitor-1 (BI-1) [72,73,74]. BI-1 is localised in the endoplasmic reticulum (ER), and controls calcium flux into and out of the ER [60], possibly through interaction with calmodulin [75]. Expression of $B I-1$ is up-regulated by pathogen inoculation
[76,77] and senescence [72,78,79]. In this study BI-1 was upregulated after 8 days of seed ageing and is likely to play a role in suppressing PCD and maintaining seed viability (Table S4). BI-1 is also up-regulated in response to water deficit, and suppresses ER stress-induced PCD [80].

Conditions of oxidative stress disturb the protein folding environment of the ER lumen leading to accumulation of unfolded and misfolded proteins. This triggers the unfolded protein response (UPR), which mitigates ER stress by up-regulating the expression of chaperones and co-chaperones of the protein folding machinery [81]. Binding protein (BiP) is the most abundant chaperone of the ER and its up-regulation is considered to be a marker of ER stress [82]. In this study BiP2 expression was induced after $12 \mathrm{~d}$, which indicates the occurrence of ER stress during seed ageing. Derlins may be involved in the targeting of misfolded proteins to the cytosol for ubiquitination [83]. Two derlin 2.2 genes were differentially expressed during seed ageing, indicating that ER-associated degradation is affected by ageing. The ubiquitin/26S proteasome system degrades misfolded proteins, 28 ubiquitin-proteasomal genes were altered in expression during ageing, indicating that this is a key ageing-responsive pathway. The ubiquitin-proteasomal system may play a vital role in the degradation of damaged proteins, such as those irreversibly oxidised during seed ageing [33]. In addition, ubiquitination may promote PCD through the targeted degradation of negative regulators of PCD by specific E3 ligases [84].

\section{Mitochondrial release of cytochrome $c$ via the permeability transition pore is repressed at the transcription level}

Multiple stimuli cause up-regulation of cytochrome $\mathrm{c}$ and cytochrome c oxidase expression as early events of PCD [85]. However, during seed ageing, the expression of both genes was down-regulated, and showed a similar trend to that observed in senescing leaves [78]. Increases in cytosolic calcium induce release of cytochrome c from mitochondria through activation of the permeability transition pore (PTP), which consists of VDAC and ANT [86]. Up-regulation of $V D A C$ has been reported in plant PCD in response to drought, cold and salicylic acid [87], Pseudomonas syringae [88] and also during the plant hypersensitive response [89]. In ageing seeds $V D A C$ was down-regulated (Table S4) and the same occurred during leaf senescence [78], which indicates that $V D A C$ may play a specific role in ageing-induced PCD that differs from PCD triggered by other stresses. ANT was also down-regulated in response to seed ageing (Table S4). Down regulation of $A N T$ is an early event in the execution phase of PCD induced by heat and senescence [78] and the defence response in Arabidopsis [90]. A decline in ANT protein synthesis may result in a decrease in ATP/ADP exchange, which is one of the earliest events of PCD [91]. Other genes that may play a role in the release of pro-apoptotic mitochondrial proteins into the cytosol are aconitases and dihydrolipoyl dehydrogenases, which appear to be particularly susceptible to oxidative stress and were up-regulated in response to seed ageing, indicating a possible involvement in redox signaling to trigger PCD $[92,93,94]$.

There have been several reports of a link between carbohydrate metabolism and PCD. For example, glyceraldehyde-3-phosphate dehydrogenase (GAPDH) has been linked to PCD in animal cells $[95,96]$. GAPDH is inhibited by oxidation of a Cys residue in the active site, which can activate a MAP kinase signalling cascade via a multistep phosphorelay [97]. In addition, disulfide bond formation between GAPDH subunits leads to aggregation, which correlates with the rate of oxidative stress-induced cell death [98]. In this study several glycolytic genes including $G A P D H$ were 
up-regulated. Likewise, Rajjou et al. [33] observed increased levels of GAPDH in a proteomic study of seed ageing, and phosphofructokinase expression was induced during silique wall senescence in Arabidopsis [79]. Both hexokinase and sucrose synthase were upregulated during seed ageing, and induction of sucrose synthase activity was also reported during accelerated ageing of sunflower seeds [99]. Hexokinase is associated with the mitochondrial membrane, and may act as a glucose sensor and regulate mitochondrial ROS levels. In animal cells hexokinases may be involved in the control of PCD [100]. Hexokinase binds to the VDAC protein to induce closure of the PTP and prevent cytochrome c release, and a similar mechanism may operate in plants [96]. Sucrose synthase is involved in inter-compartmental signalling and also interacts with VDAC possibly operating via an analogous mechanism to hexokinase [101].

\section{Seed ageing causes modulation of cysteine proteases with caspase-like activity associated with programmed cell death}

The critical point in the PCD pathway of animal cells is the activation of caspases [102,103]. Metacaspases have been identified in plants, which share sequence and structural similarity with animal caspases, but do not have caspase-like activity [104]. However, increasing evidence indicates that cysteine proteases with caspase-like activity are induced during plant PCD [105,106]. Here, in ageing seeds, two cysteine proteases, RD21 and papain, were up-regulated (Table S4), which is consistent with the proposed caspase-like role of RD21 in plant PCD [107,108]. In contrast, legumain, another cysteine protease with caspase-like activity [109] was repressed. Treatment with caspase inhibitors prior to ageing has been shown to reduce seed viability loss, which provides evidence for the involvement of caspases in seed ageing and death [4,110]. Caspase-like activity has also been linked to the proteasome. For example, the proteasome subunit PBAl has caspase-like activity [60] and the 20S proteasome is responsible for caspase- 3 activity and involved in PCD during xylem development [111]. In plant cells, the proteasome may activate the caspase cascade to induce cell death, whilst in animal cells, the proteasome-mediated steps of apoptosis are located upstream of mitochondrial changes and caspase activation, possibly involving Bcl-2 among other proteins [112]. Caspases may be subject to redox control and caspase- 3 is inhibited by $S$-glutathionylation $[45,113]$.

\section{Similarities between the seed ageing transcriptome and senescence suggest that there is overlap between the pathways leading to induction of PCD}

Whilst ageing seeds showed activation of some PCD-related genes, others such as VDAC, cytochrome $\mathrm{c}$ and cytochrome $\mathrm{c}$ oxidase were repressed. Similar expression patterns have been observed in senescence-induced PCD [78], indicating that there is considerable overlap between ageing and senescence-induced PCD routes. However, in contrast to senescence, there was little up-regulation of antioxidant genes in ageing seeds, and no senescence-activated genes (SAGs) or senescence-related genes (SRGs) were differentially expressed. Other genes that showed a similar response during seed ageing to that reported during senescence included oxidative stress-related genes (glutathione-Stransferase, mitochondrial Mn superoxide dismutase, monodehydroascorbate reductase), transcription factors (NAC, MYB family), ubiquitin-proteasome pathway genes, heat shock genes (HSP70), HR-related genes, histone genes (H2A, H2B and H3), beta-tubulin genes, two calmodulin genes ( $\mathrm{CaM} 7$ and $\mathrm{CaM} 8$ ), 12-oxophytodienoate reductase (OPRI) [34], an FtsH protease and several kinases including a calcium-dependent kinase, serine threonine protein kinases and phosphofructokinase $[78,109$, $114,115]$.

Senescence involves the active turnover and recapture of cellular material, and precedes widespread programmed cell death [116]. According to Reape and McCabe [117], senescence and PCD pathways may not overlap, with transcription of PCD genes suppressed until senescence is completed. If this is the case it is possible that cells of ageing seeds may undergo senescence prior to PCD, which could explain the similarity in expression profiles between senescing cells of Arabidopsis thaliana [78,79] and ageing pea seeds, and also the changes in expression patterns as ageing progresses. At the early stages of ageing (8 and $12 \mathrm{~d}$ ) the expression of a number of PCD-related genes were altered, which was predicted to have an overall effect of repressing PCD. For example, the up-regulation of thioredoxin- $h$, hexokinase and sucrose synthase, which are negative regulators of $\mathrm{PCD}$, and the downregulation of legumain, cytochrome $c, V D A C$ and $A \mathcal{N} T$, which are all involved in mitochondrial cytochrome $\mathrm{c}$ release and the caspase cascade. Notably, BI-1 was induced at $12 \mathrm{~d}$ of ageing, implying a role in repressing PCD in response to ageing for longer than $8 \mathrm{~d}$, but expression subsequently declined to allow PCD to proceed after $15 \mathrm{~d}$ of ageing. In accordance with this, several genes associated with PCD, including DDI1-like, NIMA-related kinase, aconitase 1 and cyclophilin $D$, were up-regulated only after $15 \mathrm{~d}$ of ageing suggesting a wider activation of PCD pathways at this point. Furthermore, repression of oxidative stress-related genes, most of which have antioxidant functions, was enhanced at the later stages of ageing consistent with the view that a decline in antioxidant capacity is required for the progression of PCD $[59,60]$. A proposed model of the ageing-induced PCD pathway in seeds is shown in Figure 7. This is a working model based on the model proposed by Kranner et al. [4], and whilst evidence is accumulating for parts of the model other parts are yet to be confirmed. Kranner et al. [4] also suggested that the mitochondrial pathway involving caspase-like protein activation by cytochrome $\mathrm{c}$ could be by-passed via direct activation of caspase-like proteins through thiol nano-switches. The absence of significant changes in $E_{\mathrm{GSSG} / 2 \mathrm{GSH}}$ until after $25 \mathrm{~d}$ of ageing, suggests that this mechanism is unlikely to be involved in the initiation of PCD during the very early stages of ageing prior to viability loss, but could play a role in the later stages. Our updated model identifies PCD-related genes that are differentially expressed during seed ageing and indicates the potential involvement of the ubiquitinproteasome and ER stress in ageing-induced PCD.

The data reported here represents the average response of all tissues within a population of seeds. Individual seeds will vary in their inherent resistance to ageing, for example antioxidant capacity. Aged samples will comprise live and dead seeds, and there will be some dead cells even in highly viable seed samples. This must be considered when interpreting the results, and may provide some explanation for the lack of a distinct ageing response in terms of processes that are up- or down-regulated. Advances in non-destructive techniques for diagnosing seed viability may in the future provide a means of sorting aged seed populations into live and dead seeds, to allow the finer details of ageing to be studied [118]. In addition, techniques such as laser micro-dissection show promise for enabling tissue specific analyses, which will prove invaluable in understanding processes such as ageing in different seed tissues [119].

This study provides a comprehensive analysis of the relationship between the cellular redox state and global gene expression during seed ageing. The existence of a regulated cell death process is 
Oxidative stress related genes

\begin{tabular}{|c|c|c|c|}
\hline 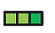 & GPX (put.) & 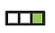 & Oxidoreductas \\
\hline 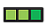 & Peroxidase 42 & 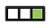 & GRX S15 \\
\hline שח 2 2 2 & MDHAR (put.) & 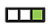 & GST (put.) \\
\hline 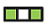 & MnSOD 2 (mit.) & 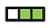 & $P R \times 2$ \\
\hline 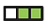 & GST & & \\
\hline שח 2 2 20 & GSH-FDH & 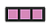 & $T R X-H$ \\
\hline سח & Peroxidase (put.) & 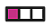 & GSH-FDH \\
\hline
\end{tabular}

Mitochondrial PCD-related genes

\begin{tabular}{|c|c|c|c|}
\hline 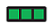 & ANT & 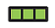 & Pyruvate DHE1 $\beta$ \\
\hline שי & Cyt c-1 & प्रा & Cyt c oxidase \\
\hline שח & VDAC & & \\
\hline 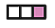 & Mit. processing peptidase & 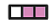 & Dihydrolipoyl DH precursor \\
\hline 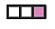 & Pyruvate DHE1 $\beta$ precursor & שा & Hexokinase $(H K)$ \\
\hline 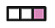 & Aconitase 1 & שי & Aconitase (put) \\
\hline 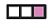 & Cyclophilin D (СурD) & די & Sucrose synthase (SuS; put.) \\
\hline
\end{tabular}

Genes involved in PCD regulation

\begin{tabular}{|c|c|c|c|}
\hline 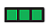 & Histone deactylase HD2-P39 & 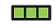 & Histone deacetylase $2 a$ \\
\hline שי & Accelerated cell death 1 & 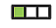 & Legumain \\
\hline 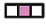 & RD22 precursor & 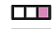 & MÄ 3 domain-containing protein \\
\hline שח & $B I-1$ & प्र & Sentrin-specific protein (put.) \\
\hline 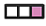 & DDI1-like & 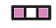 & Papain \\
\hline 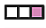 & NIMA-related kinase & 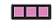 & KNAT4 \\
\hline 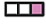 & RD22 precursor & 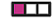 & $R D 21$ \\
\hline
\end{tabular}

SCF complex associated genes

\begin{tabular}{|c|c|c|c|}
\hline प्र & F-box & 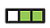 & UBC spm2 \\
\hline प्र & SKP1-like $1 B$ & טי & E3 UQ-protein ligase $L R S A M$ \\
\hline 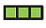 & UBC1 & 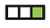 & Tubby-like F-box protein 10 \\
\hline प & E3 UQ-protein ligase CIP8 & שם & COP9 signalosome subunit 8 \\
\hline שי & UBC10 & שי & UBC putative \\
\hline שי & Polyubiquitin & שי & Cullin 1 \\
\hline שי & Ubiquitin & די & Tubby-like F-box protein 7 \\
\hline שי & UBC10 & पा & Tubby-like F-box protein 3 \\
\hline די & quitin & & \\
\hline
\end{tabular}

\begin{tabular}{|c|c|c|c|}
\hline \multicolumn{4}{|c|}{$26 S$ proteasome genes } \\
\hline 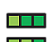 & 26S non-ATPase subunit 14 & प्राप & Endopeptidase \\
\hline שा & 26S ATPase subunit RPT6a & पात & UQ fusion degradation protein 1 \\
\hline 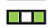 & $20 S b$ subunit $A$ & שי & $26 S$ non-ATPase subunit 3 \\
\hline سח & $\beta$ subunit 3 (put.) & & \\
\hline שי & $26 S$ non-ATPase subunit $3 a$ & पा & $\beta$ subunit 3 (put.) \\
\hline एाप & $26 S$ non-ATPase subunit 3 & $\bar{\square}$ & UQ-specific protease \\
\hline \multicolumn{4}{|c|}{ Other genes } \\
\hline प्य & Heat shock protein & די & Heat shock protein 70.1 \\
\hline पा & Heat shock $70 \mathrm{kDa}$ protein & पात & $179 \mathrm{kDa}$ class // heat shock protein \\
\hline 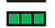 & Heat shock protein $81-3$ & 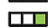 & $18.1 \mathrm{kDa}$ class I heat shock protein \\
\hline 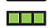 & Calmodulin-7 (CaM7) & שח & 14-3-3-like protein A (VFA-1433A) \\
\hline سד & 14-3-3-like protein & पा & BiP2 \\
\hline
\end{tabular}

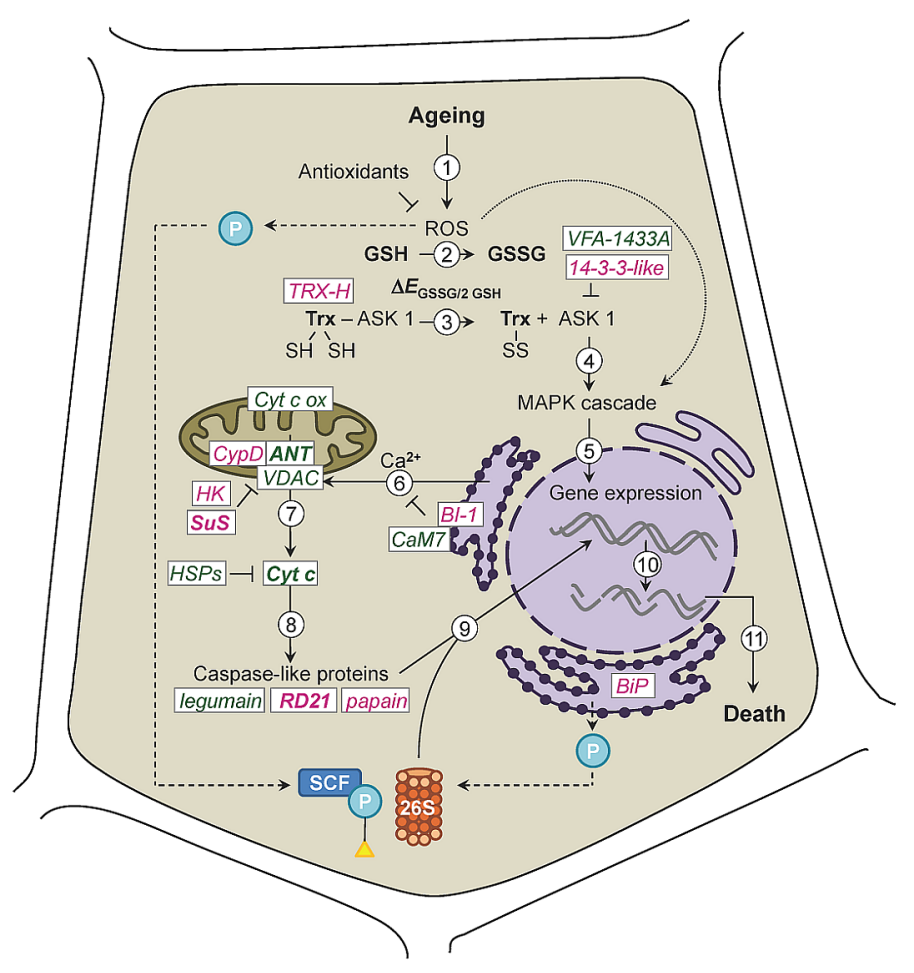

Figure 7. A model of events leading to programmed cell death during seed ageing. Differentially expressed PCD-related genes were mapped onto the model proposed by Kranner et al. [4] (solid arrows). ROS formed during ageing (1) are scavenged by GSH leading to an increase in $E_{\mathrm{GSSG} / 2 \mathrm{GSH}}(2)$, which causes the apoptosis signal-regulating kinase (ASK 1 ) to be split from thioredoxin (Trx; TRX-H; 3). ASK1 activates a MAPK cascade (4) leading to changes in gene expression (5). ROS may also participate directly in signalling pathways to activate MAP kinase cascades (dotted arrow). $\mathrm{Ca}^{2+}$ is released from the ER (6), which induces release of cyt c from the mitochondrion (7). Cyt c activates caspases (8) and a downstream proteolytic cascade (9) which leads to the breakdown of structural and nuclear proteins and activation of nucleases which cleave DNA (10) as part of the execution phase of PCD leading to cell death (11). ROS cause protein oxidation, and the damaged and mis-folded (due to ER stress) proteins (P) are degraded by the ubiquitin-proteasome pathway (dashed arrows). The ubiquitin-proteasome has been linked with activation of the caspase proteolytic cascade and some proteasome subunits have caspase-like activity, which may offer an alternative route to PCD. The coloured blocks on the left-hand side indicate the ratio of expression of genes involved in the model at three different ageing time points (from left to right: 8,12 and 15 days) to expression in non-aged seeds. Expression values corresponding to a $\log _{2}$ ratio $\geq 1.0$ or $\leq-1.0$ are shaded in light magenta (up-regulation) or light green (down-regulation), and those which were changed by a $\log _{2}$ ratio of $\geq 1.5$ or $\leq-1.5$ are shaded in dark magenta (up-regulation) or dark green (down-regulation). White blocks indicate no change in expression between aged and non-aged seed.

doi:10.1371/journal.pone.0078471.g007

demonstrated by the observation of DNA laddering and transcriptional modulation of genes associated with programmed cell death. Studies of sunflower seed ageing showed that cell death occurred in a synchronous manner, in which all cells simultaneously underwent PCD [120]. It was proposed that ageing induces PCD in seeds once cellular damage has exceeded the capacity for repair. Seed MC and storage temperature are key determinants of the rate of ageing, and probably also of the mechanisms leading to seed viability loss. For example, in rye seeds stored at $40^{\circ} \mathrm{C}$ with $10 \% \mathrm{MC}$ nucleic acid degradation resulted in randomly sized DNA fragments, whilst at $14 \%$ MG DNA fragments of around 160 base pairs, characteristic of inter-nucleosomal cleavage associated with PCD, were observed [121]. Long term studies to dissect the ageing process at lower temperatures and $\mathrm{RH}$, such as the conditions used for ex situ seed storage (e.g. $-20^{\circ} \mathrm{C}$ and $15 \% \mathrm{RH}$ ) may enable the elucidation of molecular markers that could be used to diagnose seed deterioration prior to viability loss, which would be a valuable tool for seed conservation and agriculture. In addition, large scale investigations which combine transcriptomic, proteomic and metabolomic data are necessary to provide the missing pieces in the seed ageing puzzle. 


\section{Supporting Information}

Figure S1 Loss of RNA integrity induced by ageing of pea seeds. Electropherograms of total RNA samples from seeds of selected ageing treatments: (A) non-aged (0 days); (B) 12 days; (C) 25 days. RNA integrity number (RIN) values were determined using Agilent 2100 Expert software. RNA quality was considered good if the electropherogram showed two distinct peaks for the 25S and 18S bands and a flat baseline. When two peaks were still visible, but the baseline was elevated, RNA was considered partially degraded. RNA was deemed strongly degraded when the two peaks disappeared. Ten categories were defined ranging from 1 (totally degraded RNA) to 10 (intact RNA). Parameters are explained in (A): region A represents low molecular weight RNA; the presence of peaks or smearing in this region indicates the extent of RNA degradation. Peak B and Peak D represent $18 \mathrm{~S}$ and $25 \mathrm{~S}$ ribosomal RNA, respectively. The presence of peaks in region $\mathrm{C}$ between the $18 \mathrm{~S}$ and $25 \mathrm{~S}$ peaks indicate degradation of $25 \mathrm{~S}$ ribosomal RNA. High molecular weight RNA would appear in region $\mathrm{E}$; peaks or smearing in this region may also result from genomic DNA contamination. Gel-like images of RNA are shown on the far right, with distinct lines for 25S and 18S RNA in (A). (TIF)

Figure S2 Hierarchical cluster analysis of 717 ageingresponsive genes. Genes that were differentially expressed $(\geq 2$ fold change in expression compared to non-aged controls) at one or more time points $(8 \mathrm{~d}, 12 \mathrm{~d}$ and $15 \mathrm{~d})$ during ageing of Pisum sativum seeds. Genes (rows) and experiments (columns) were clustered with The Institute for Genomic Research (TIGR) Multi-experiment Viewer software using Euclidean distance and complete linkage [27].

(TIFF)

Figure S3 Correlation analysis of gene expression profiles at three time points during ageing of Pisum sativum seeds (0 d vs 8 d, 0 d vs 12 d and 0 d vs 15 d). (TIFF)

Figure S4 Experimental work flow for the gene expression studies using qRT-PGR. Seed ageing causes RNA degradation, so standard procedures for qRT-PCR could not be followed and a new approach was developed for the assessment of gene expression patterns. Prior to RT, equal amounts of total RNA were spiked with a defined amount of human RNA as an internal standard. Gene expression levels of the human $P B G D$ gene were used to assess cDNA synthesis efficiency and to enable normalization of target pea genes.

(TIFF)

Figure S5 Non-normalised expression of selected genes during seed ageing determined using qRT-PCR. (a) Distribution of non-normalised expression values of all samples for glucose-6-phosphate dehydrogenase $(G 6 P D H)$, glutathione reductase $(G R)$, voltage-dependent anion channel $(V D A C)$, adenine nucleotide translocator $(A \mathcal{N} T)$, $\beta$-Tubulin $3(T u b)$, Actin $1(A c t)$ and elongation Factor- $1 \alpha(e F)$ as determined by qRT-PCR analysis. (b) to (i) Non-normalised expression values during ageing. Data points are means $(n=5)$. Solid lines represent linear regression and dotted curves indicate 95\% confidence intervals. Asterisks denote genes with a regression slope deviating significantly from zero (linear regression analysis, $P<0.001)$. Correlation coefficient $\left(\mathrm{R}^{2}\right)$ of regression analysis: $P B G D=0.3801 ; \quad G 6 P D H=0.04478 ; \quad G R=$
$0.9777 ; \quad V D A C=0.8397 ; A N T=0.9619 ; \quad T u b=0.85 ; A c t=0.8619 ;$ $e F=0.8756$.

(TIFF)

Table S1 Primer sequences used for qRT-PGR analysis of $\beta$-tubulin-3 $(T u b)$, elongation factor-1 $\alpha(e F)$, actin 1 $(A c t)$, glutathione reductase $(G R)$, glucose-6-phosphate dehydrogenase $(G 6 P D H)$, voltage-dependent anion-selective channel (VDAC) and an adenine nucleotide translocator $(A N T)$ gene expression.

(DOCX)

Table S2 Genes showing altered expression during the artificial ageing of pea seeds. Expression values correspond to the log transformed ratio of expression between aged $(8,12$ and $15 \mathrm{~d})$ and non-aged $(0 \mathrm{~d})$ seed. Genes representing at least a 2-fold change $\left(\log _{2}\right.$ ratio $\geq 1$ for up-regulation and $\leq-1$ for downregulation) at one or more time points are included. Genes which showed a change in expression corresponding to a $\log _{2}$ ratio $\geq 1.0$ or $\leq-1.0$ are shaded in light magenta (up-regulation) or light green (down-regulation), and those which were changed by a $\log _{2}$ ratio of $\geq 1.5$ or $\leq-1.5$ are shaded in dark magenta (upregulation) or dark green (down-regulation). Genes that were assigned a KOG annotation are arranged in $\mathrm{KOG}$ functional categories.

(XLS)

Table S3 Hierarchical clustering of ageing-responsive genes. All 717 differentially expressed genes were grouped into 16 clusters according to expression profiles during the ageing time course. Genes representing at least a 2 -fold change $\left(\log _{2}\right.$ ratio $\geq 1.0$ or $\leq-1.0)$ at one or more time points are included. Expression values corresponding to a $\log _{2}$ ratio $\geq 1.0$ or $\leq-1.0$ are shaded in light magenta (up-regulation) or light green (down-regulation), and those which were changed by a $\log _{2}$ ratio of $\geq 1.5$ or $\leq-1.5$ are shaded in dark magenta (up-regulation) or dark green (downregulation). For KOG annotated genes, the functional category ID and description are shown.

(XLS)

Table S4 Functional classification of ageing-responsive genes related to $\mathbf{P C D}$, oxidative stress, ubiquitinproteolysis and signaling etc. Genes representing at least a 2 -fold change $\left(\log _{2}\right.$ ratio $\geq 1.0$ or $\leq-1.0$ ) at one or more time points are included. Expression values corresponding to a $\log _{2}$ ratio $\geq 1.0$ or $\leq-1.0$ are shaded in light magenta (up-regulation) or light green (down-regulation), and those which were changed by a $\log _{2}$ ratio of $\geq 1.5$ or $\leq-1.5$ are shaded in dark magenta (upregulation) or dark green (down-regulation). For KOG annotated genes, the functional category ID and description are shown, and for all genes the cluster to which each gene belongs is also shown. (XLS)

\section{Acknowledgments}

We thank Prof. Weiqi Li and Dr Erwann Arc for comments on the manuscript and Irene López-Vidriero, Eduardo Gil and Jose M. Franco for assistance with the microarray analysis.

\section{Author Contributions}

Conceived and designed the experiments: IK HC DO OL KG HK GLM. Performed the experiments: HC DO KG. Analyzed the data: LC DO HC KG. Contributed reagents/materials/analysis tools: HK OL GLM. Wrote the paper: LG HC DO KG IK. 


\section{References}

1. Dell'Aquila A (1994) Wheat seed ageing and embryo protein degradation. Seed Sci Res 4: 293-298.

2. Murthy UM, Kumar PP, Sun WQ (2003) Mechanisms of seed ageing under different storage conditions for Vigna radiata (L) Wilczek: lipid peroxidation, sugar hydrolysis, maillard reactions and their relationship to glass state transition. J Exp Bot 54: 1057-1067.

3. Bailly C (2004) Active oxygen species and antioxidants in seed biology Seed Sci Res 14: 93-107.

4. Kranner I, Birtić S, Anderson KM, Pritchard HW (2006) Glutathione half-cell reduction potential: a universal stress marker and modulator of programmed cell death? Free Radical Bio Med 40: 2155-2165.

5. Kenyon CJ (2010) The genetics of ageing. Nature 464: 504-512.

6. Nakabayashi K, Okamoto M, Koshiba T, Kamiya Y, Nambara E (2005) Genome-wide profiling of stored mRNA in Arabidopsis thaliana seed germination: epigenetic and genetic regulation of transcription in seed. Plant J 41: 697709.

7. Holdsworth MJ, Finch-Savage WE, Grappin P, Job D (2008) Post-genomics dissection of seed dormancy and germination. Trends Plant Sci 13: 7-13.

8. Leubner-Metzger G (2005) Beta-1,3-glucanase gene expression in low-hydrated seeds as a mechanism for dormancy release during tobacco after-ripening. Plant J 41: 133-145.

9. Bove J, Lucas P, Godin B, Oge L, Jullien M, et al. (2005) Gene expression analysis by cDNA-AFLP highlights a set of new signaling networks and translational control during seed dormancy breaking in Nicotiana plumbaginifolia. Plant Mol Biol 57: 593-612.

10. Leymarie J, Bruneaux E, Gibot-Leclerc S, Corbineau F (2007) Identification of transcripts potentially involved in barley seed germination and dormancy using cDNA-AFLP. J Exp Bot 58: 425-437.

11. Bazin J, Langlade N, Vincourt P, Arribat S, Balzergue S, et al. (2011) Targeted mRNA oxidation regulates sunflower seed dormancy alleviation during dry after-ripening. Plant Cell 23: 2196-2208.

12. Johnson RR, Dyer WE (2000) Degradation of endosperm mRNAs during dry afterripening of cereal grains. Seed Sci Res 10: 233-241.

13. Delouche JC, Baskin CC (1973) Accelerated ageing techniques for predicting the relative storability of seed lots. Seed Sci Technol 1: 427-452.

14. Kranner I, Chen HY, Pritchard HW, Pearce SR, Birtić S (2011) Internucleosomal DNA fragmentation and loss of RNA integrity during seed ageing. Plant Growth Regul 63: 63-72.

15. Colville L, Bradley EL, Lloyd AS, Pritchard HW, Castle L, et al. (2012) Volatile fingerprints of seeds of four species indicate the involvement of alcoholic fermentation, lipid peroxidation, and Maillard reactions in seed deterioration during ageing and desiccation stress. J Exp Bot 63: 6519-6530.

16. Oñate-Sánchez L, Vicente-Carbajosa J (2008) DNA-free RNA isolation protocols for Arabidopsis thaliana, including seeds and siliques. BMS Research Notes 1: 93-100.

17. Copois V, Bibeau F, Bascoul-Mollevi C, Salvetat N, Chalbos P, et al. (2007) Impact of RNA degradation on gene expression profile: Assessment of different methods to reliably determine RNA quality. J Biotechnol 127: 549-559.

18. Kranner I, Grill D (1996) Determination of glutathione and glutathione disulphide in lichens: a comparison of frequently used methods. Phytochem Analysis 7: 24-28.

19. Birtić S, Colville L, Pritchard HW, Pearce SR, Kranner I (2011) Mathematically combined half-cell reduction potentials of low-molecularweight thiols as markers of seed ageing. Free Radical Res 45: 1093-1102.

20. Schafer FQ Buettner GR (2001) Redox environment of the cell as viewed through the redox state of the glutathione disulfide/ glutathione couple. Free Radical Bio Med 30: 1191-1212.

21. Kranner I (1998) Determination of glutathione, glutathione disulphide, and two related enzymes, glutathione reductase and glutcose-6-phosphate dehydrogenase, in fungal and plant cells. In: Varma A, editor. Mycorrhiza Manual. Berlin: Springer. pp.227-241.

22. Weigelt K, Küster H, Radchuk R, Müller M, Weichert H, et al. (2008) Increasing amino acid supply in pea embryos reveals specific interactions of $\mathrm{N}$ and $\mathrm{C}$ metabolism, and highlights the importance of mitochondrial metabolism. Plant J 55: 909-926.

23. Smyth GK, Speed T (2003) Normalization of cDNA microarray data. Methods 31: $265-273$.

24. Smyth GK (2004) Linear models and empirical bayes methods for assessing differential expression in microarray experiments. Stat Appl Genet Mol Biol 3: Article 3.

25. Ihaka R, Gentleman R (1996) R: a language for data analysis and graphics. J Comput Graph Stat 5: 299-314.

26. Benjamini Y, Hochberg Y (1995) Controlling the false discovery rate: a practical and powerful approach to multiple testing. J R Stat Soc Series B: 289300 .

27. Saeed AI, Sharov V, White J, Li J, Liang W, et al. (2003) TM4: a free, opensource system for microarray data management and analysis. Biotechniques 34 : 374-378.

28. Edgar R, Domrachev M, Lash AE (2002) Gene Expression Omnibus: NCBI gene expression and hybridization array data repository. Nucleic Acids Res 30: 207-210.
29. Zhao S, Fernald RD (2005) Comprehensive algorithm for quantitative realtime polymerase chain reaction. J Comput Biol 12: 1047-1064.

30. Pfaffl MW (2001) A new mathematical model for relative quantification in realtime RT-PCR. Nucleic Acids Res 29: 2003-2007.

31. Ludwig AA, Romeis T, Jones JDG (2004) CDPK-mediated signalling pathways: specificity and cross-talk. J Exp Bot 55: 181-188.

32. Xin X, Lin XH, Zhou YC, Chen XL, Liu X, et al. (2011) Proteome analysis of maize seeds: the effect of artificial ageing. Physiol Plant 143: 126-138.

33. Rajjou L, Lovigny Y, Groot SPG, Belghazi M, Job C, et al. (2008) Proteomewide characterization of seeds ageing in Arabidopsis: A comparison between artificial and natural ageing protocols. Plant Physiol 148: 620-641.

34. He Y, Gan S (2001) Identical promoter elements are involved in the regulation of the OPR1 gene by senescence and jasmonic acid in Arabidopsis. Plant Mol Biol 47: 595-605.

35. Shen WH, Parmentier Y, Hellmann H, Lechner E, Dong A, et al. (2002) Null mutation of AtCUL1 causes arrest in early embryogenesis in Arabidopsis. Mol Biol Cell 13: 1916-1928.

36. Polci R, Peng A, Chen PL, Riley DJ, Chen Y (2004) NIMA-related protein kinase 1 is involved early in the ionizing radiation-induced DNA damage response. Cancer Res 64: 8800-8803.

37. Shibahara K, Asano M, Ishida Y, Aoki T, Koike T, et al. (1995) Isolation of a novel mouse gene MA-3 that is induced upon programmed cell death. Gene 166: 297-301.

38. Abe H, Yamaguchi-shinozaki K, Urao T, Iwasaki T, Hosokawa D, et al. (1997) Role of Arabidopsis MYC and MYB homologs in drought-and abscisic acidregulated gene expression. Plant Cell 9: 1859-1868.

39. Diaz M, Achkor H, Titarenko E, Martinez MC (2003) The gene encoding glutathione-dependent formaldehyde dehydrogenase/GSNO reductase is responsive to wounding, jasmonic acid and salicylic acid. FEBS Lett 543: 136-139.

40. Pérez-Novo CA, Claeys C, Speleman F, van Cauwenberge P, Bachert C, et al. (2005) Impact of RNA quality on reference gene expression stability. Biotechniques 39: 52-56.

41. Graeber K, Linkies A, Wood ATA, Leubner-Metzger G (2011) A guideline to family-wide comparative state-of-the-art quantitative RT-PCR analysis exemplified with a Brassicaceae cross-species seed germination case study. Plant Cell 23: 2045-2063.

42. Czechowski T, Stitt M, Altmann T, Udvardi MK, Scheible WR (2005) Genome-wide identification and testing of superior reference genes for transcript normalization in Arabidopsis. Plant Physiol 139: 5-17.

43. Huggett J, Dheda K, Bustin S, Zumla A (2005) Real-time RT-PCR normalisation; strategies and considerations. Genes Immun 6: 279-284.

44. Gilsbach R, Kouta M, Bonisch H, Bruss M (2006) Comparison of in vitro and in vivo reference genes for internal standardization of real-time PCR data. Biotechniques 40: 173-177.

45. Dalle-Donne I, Rossi R, Colombo G, Giustarini D, Milzani A (2009) Protein Sglutathionylation: a regulatory device from bacteria to humans. Trends Biochem Sci 34: 85-96.

46. Di Stefano A, Frosali S, Leonini A, Ettorre A, Priora R, et al. (2006) GSH depletion, protein S-glutathionylation and mitochondrial transmembrane potential hyperpolarization are early events in initiation of cell death induced by a mixture of isothiazolinones in HL60 cells. BBA - Mol Cell Res 1763: 214 225.

47. Foyer CH, Souriau N, Perret S, Lelandais M, Kunert KJ, et al. (1995) Overexpression of glutathione reductase but not glutathione synthetase leads to increases in antioxidant capacity and resistance to photoinhibition in poplar trees. Plant Physiol 109: 1047-1057.

48. Cereser C, Boget S, Parvaz P, Revol A (2001) Thiram-induced cytotoxicity is accompanied by a rapid and drastic oxidation of reduced glutathione with consecutive lipid peroxidation and cell death. Toxicology 163: 153-162.

49. Zhao Y, Seefeldt T, Chen W, Wang XQ Matthees D, et al. (2009) Effects of glutathione reductase inhibition on cellular thiol redox state and related systems. Arch Biochem Biophys 485: 56-62.

50. Pastori GM, Trippi VS (1992) Oxidative stress induces high rate of glutathione reductase synthesis in a drought-resistant maize strain. Plant Cell Physiol 33: 957-961.

51. Pias EK, Aw TY (2002) Early redox imbalance mediates hydroperoxideinduced apoptosis in mitotic competent undifferentiated PC-12 cells. Cell Death Differ 9: 1007-1016.

52. El Yahyaoui F, Kuster H, Ben Amor B, Hohnjec N, Puhler A, et al. (2004) Expression profiling in Medicago truncatula identifies more than 750 genes differentially expressed during nodulation, including many potential regulators of the symbiotic program. Plant Physiol 136: 3159-3176.

53. Stone SL, Hauksdottir H, Troy A, Herschleb J, Kraft E, et al. (2005) Functional analysis of the RING-type ubiquitin ligase family of Arabidopsis. Plant Physiol 137: 13-30.

54. Del Prete MJ, Robles MS, Guao A, Martinez C, Izquierdo M, et al. (2002) Degradation of cellular mRNA is a general early apoptosis-induced event. FASEB J 16: 2003-2005. 
55. Murphy NB, Welburn SC (1997) Programmed cell death in procyclic trypanosome brucei rhodesiense is associated with differential expression of mRNA. Cell Death Differ 4: 365-370.

56. Nasirudeen AMA, Tan KSW, Singh M, Yap EH (2001) Programmed cell death in a human intestinal parasite, Blastocystis hominis. Parasitology 123: 235246.

57. Kuthanova A, Opatrny Z, Fischer L (2008) Is internucleosomal DNA fragmentation an indicator of programmed death in plant cells? J Exp Bot 59: $2233-2240$.

58. Kibinza S, Bazin J, Bailly C, Farrant JM, Corbineau F, et al. (2011) Catalase is a key enzyme in seed recovery from ageing during priming. Plant Sci 181: 309315.

59. He X, Kermode AR (2010) Programmed cell death of the megagametophyte during post-germinative growth of white spruce (Picea glauca) seeds is regulated by reactive oxygen species and the ubiquitin-mediated proteolysis system. Plant Cell Physiol 51: 1707-1720.

60. De Pinto MC, Locato V, De Gara L (2012) Redox regulation in plant programmed cell death. Plant Cell Environ 35: 234-244.

61. Stein RJ, Ricachenevsky FK, Fett JP (2009) Differential regulation of the two rice ferritin genes (OsFER1 and OsFER2). Plant Sci 177: 563-569.

62. Cazalis R, Pulido P, Aussenac T, Pérez-Ruiz JM, Cejudo FJ (2006) Cloning and characterization of three thioredoxin $h$ isoforms from wheat showing differential expression in seeds. J Exp Bot 57: 2165-2172.

63. Chrestensen CA, Starke DW, Mieyal JJ (2000) Acute cadmium exposure inactivates thioltransferase (glutaredoxin) inhibits intracellular reduction of protein-glutathionyl-mixed disulfides, and initiates apoptosis. J Biol Chem 275: 26556-26565

64. Nordberg J, Arner ESJ (2001) Reactive oxygen species, antioxidants, and the mammalian thioredoxin system. Free Radical Bio Med 31: 1287-1312.

65. Song JJ, Lee YJ (2003) Differential role of glutaredoxin and thioredoxin in metabolic oxidative stress-induced activation of apoptosis signal-regulating kinase 1. Biochem J 373: 845-853.

66. Kim SY, Kim TJ, Lee KY (2008) A novel function of peroxiredoxin 1 (Prx-1) in apoptosis signal-regulating kinase 1 (ASK1)-mediated signaling pathway. FEBS Lett 582: 1913-1918.

67. Zhang LX, Chen J, Fu HA (1999) Suppression of apoptosis signal-regulating kinase 1-induced cell death by 14-3-3 proteins. P Natl Acad Sci USA 96: 8511 8515.

68. Goldman EH, Chen L, Fu H (2004) Activation of apoptosis signal-regulating kinase 1 by reactive oxygen species through dephosphorylation at serine 967 and 14-3-3 dissociation. J Biol Chem 279: 10442-10449.

69. Thomas SG, Franklin-Tong VE (2004) Self-incompatibility triggers programmed cell death in Papaver pollen. Nature 429: 305-309.

70. Reape TJ, Molony EM, McCabe PF (2008) Programmed cell death in plants: distinguishing between different modes. J Exp Bot 59: 435-444.

71. Chen XY, Wang Y, Li JY, Jiang AL, Cheng YW, et al. (2009) Mitochondrial proteome during salt stress-induced programmed cell death in rice. Plant Physiol Biochem 47: 407-415.

72. Bolduc N, Ouellet M, Pitre F, Brisson LF (2003) Molecular characterization of two plant BI-1 homologues which suppress Bax-induced apoptosis in human 293 cells. Planta 216: 377-386.

73. Kawai-Yamada M, Ohori Y, Uchimiya H (2004) Dissection of Arabidopsis Bax inhibitor-1 suppressing Bax-, hydrogen peroxide-, and salicylic acid-induced cell death. Plant Cell 16: 21-32.

74. Watanabe N, Lam E (2006) Arabidopsis Bax inhibitor-1 functions as attenuator of biotic and abiotic types of cell death. Plant J 45: 884-894.

75. Ihara-Ohori Y, Nagano M, Muto S, Uchimiya H, Kawai-Yamada M (2007) Cell death suppressor Arabidopsis Bax inhibitor-1 is associated with calmodulin binding and ion homeostasis. Plant Physiol 143: 650-660.

76. Sanchez P, Zabala MD, Grant M (2000) AtBI-1, a plant homologue of Bax inhibitor-1, suppresses Bax-induced cell death in yeast and is rapidly upregulated during wounding and pathogen challenge. Plant J 21: 393-399.

77. Hückelhoven R, Dechert C, Trujillo M, Kogel KH (2001) Differential expression of putative cell death regulator genes in near-isogenic, resistant and susceptible barley lines during interaction with the powdery mildew fungus. Plant Mol Biol 47: 739-748.

78. Swidzinski JA, Sweetlove LJ, Leaver CJ (2002) A custom microarray analysis of gene expression during programmed cell death in Arabidopsis thaliana. Plant $\mathrm{J} 30$ : 431-446.

79. Wagstaff C, Yang TJW, Stead AD, Buchanan-Wollaston V, Roberts JA (2009) A molecular and structural characterization of senescing Arabidopsis siliques and comparison of transcriptional profiles with senescing petals and leaves. Plant J 57: 690-705.

80. Duan YF, Zhang WS, Li B, Wang YN, Li KX, et al. (2010) An endoplasmic reticulum response pathway mediates programmed cell death of root tip induced by water stress in Arabidopsis. New Phytol 186: 681-695.

81. Liu J-X, Howell SH (2010) Endoplasmic reticulum protein quality control and its relationship to environmental stress responses in plants. Plant Cell 22: 2930 2942.

82. Adamakis I-DS, Panteris E, Eleftheriou EP (2011) The fatal effect of tungsten on Pisum sativum L root cells: indications for endoplasmic reticulum stressinduced programmed cell death. Planta 234: 21-34.

83. Kirst ME, Meyer DJ, Gibbon BC, Jung R, Boston RS (2005) Identification and characterization of endoplasmic reticulum-associated degradation proteins differentially affected by endoplasmic reticulum stress. Plant Physiol 138: 218231.

84. Lin S-S, Martin R, Mongrand S, Vandenabeele S, Chen K-C, et al. (2008) RING1 E3 ligase localizes to plasma membrane lipid rafts to trigger FB1induced programmed cell death in Arabidopsis. Plant J 56: 550-561.

85. Chandra D, Liu JW, Tang DG (2002) Early mitochondrial activation and cytochrome c up-regulation during apoptosis. J Biol Chem 277: 50842-50854.

86. Godbole A, Varghese J, Sarin A, Mathew MK (2003) VDAC is a conserved element of death pathways in plant and animal systems. BBA-Mol Cell Res 1642: 87-96.

87. Desai MK, Mishra RN, Verma D, Nair S, Sopory SK, et al. (2006) Structural and functional analysis of a salt stress inducible gene encoding voltage dependent anion channel (VDAC) from pearl millet (Pennisetum glaucum). Plant Physiol Biochem 44: 483-493.

88. Tateda C, Yamashita K, Takahashi F, Kusano T, Takahashi Y (2009) Plant voltage-dependent anion channels are involved in host defense against Pseudomonas cichorii and in Bax-induced cell death. Plant Cell Reports 28: 41-51.

89. Lacomme C, Roby D (1999) Identification of new early markers of the hypersensitive response in Arabidopsis thaliana. FEBS Lett 459: 149-153.

90. Schenk PM, Kazan K, Wilson I, Anderson JP, Richmond T, et al. (2000) Coordinated plant defense responses in Arabidopsis revealed by microarray analysis. P Natl Acad Sci USA 97: 11655-11660.

91. Adrain C, Martin SJ (2001) The mitochondrial apoptosome: a killer unleashed by the cytochrome seas. Trends Biochem Sci 26: 390-397.

92. Swidzinski JA, Leaver CJ, Sweetlove LJ (2004) A proteomic analysis of plant programmed cell death. Phytochemistry 65: 1829-1838.

93. Amirsadeghi S, Robson CA, Vanlerberghe GC (2007) The role of the mitochondrion in plant responses to biotic stress. Physiol Plant 129: 253-266.

94. Moeder W, Del Pozo O, Navarre DA, Martin GB, Klessig DF (2007) Aconitase plays a role in regulating resistance to oxidative stress and cell death in Arabidopsis and Nicotiana benthamiana. Plant Mol Biol 63: 273-287.

95. Ishitani R, Sunaga K, Hirano A, Saunders P, Katsube N, et al. (1996) Evidence that glyceraldehyde-3-phosphate dehydrogenase is involved in age-induced apoptosis in mature cerebellar neurons in culture. J Neurochem 66: 928-935.

96. Kim M, Lim J-H, Ahn CS, Park K, Kim GT, et al. (2006) Mitochondriaassociated hexokinases play a role in the control of programmed cell death in Nicotiana benthamiana. Plant Cell 18: 2341-2355.

97. Morigasaki S, Shimada K, Ikner A, Yanagida M, Shiozaki K (2008) Glycolytic enzyme GAPDH promotes peroxide stress signaling through multistep phosphorelay to MAPK cascade. Mol Cell 30: 108-113.

98. Brandes N, Schmitt S, Jakob U (2009) Thiol-based switches in eukaryotic proteins. Antioxid Redox Sign 11: 997-1014.

99. Sital JS, Sandhu AS, Sharma S (2008) Biochemical changes associated with accelerated ageing of sunflower (Helianthus annus L) seeds. Indian J Agr Biochem 21: 16-20.

100. Bolouri-Moghaddam MR, Le Roy K, Xiang L, Rolland F, Van den Ende W (2010) Sugar signalling and antioxidant network connections in plant cells. FEBS J 277: 2022-2037.

101. Subbaiah CC, Palaniappan A, Duncan K, Rhoads DM, Huber SC, et al. (2006) Mitochondrial localization and putative signaling function of sucrose synthase in maize. J Biol Chem 281: 15625-15635.

102. Martins LM, Earnshaw WC (1997) Apoptosis: alive and kicking in 1997. Trends Cell Biol 7: 111-114.

103. Solomon M, Belenghi B, Delledonne M, Menachem E, Levine A (1999) The involvement of cysteine proteases and protease inhibitor genes in the regulation of programmed cell death in plants. Plant Cell 11: 431-443.

104. Bonneau L, Ge Y, Drury GE, Gallois P (2008) What happened to plant caspases? J Exp Bot 59: 491-499.

105. Minami A. Fukuda H (1995) Transient and specific expression of a cysteine endopeptidase associated with autolysis during differentiation of Zinnia mesophyll cells into tracheary elements. Plant Cell Physiol 36: 1599-1606.

106. Drake R, John I, Farrell A, Cooper W, Schuch W, et al. (1996) Isolation and analysis of cDNAs encoding tomato cysteine proteasese expressed during leaf senescence. Plant Mol Biol 30: 755-767.

107. Lam E, Pozo O (2000) Caspase-like protease involvement in the control of plant cell death. Plant Mol Biol 44: 417-428.

108. Watanabe N, Lam E (2004) Recent advance in the study of caspase-like proteases and Bax inhibitor-1 in plants: their possible roles as regulator of programmed cell death. Mol Plant Pathol 5: 65-70.

109. Roberts IN, Caputo C, Criado MV, Funk C (2012) Senescence-associated proteases in plants. Physiol Plant 145: 130-139.

110. Hu D, Ma G, Wang Q, Yao J, Wang Y, et al. (2012) Spatial and temporal nature of reactive oxygen species production and programmed cell death in elm (Ulmus pumila L) seeds during controlled deterioration. Plant Cell Environ 35: 2045-2059.

111. Han J-J, Lin W, Oda Y, Cui K-M, Fukuda H, et al. (2012) The proteasome is responsible for caspase-3-like activity during xylem development. Plant J 72: 129-141.

112. Kim M, Anh J-W, Jin U-H, Choi D, Park K-H, et al. (2003) Activation of the programmed cell death pathway by inhibition of proteasome function in plants. J Biol Chem 278: 19406-19415.

113. Huang Z, Pinto JT, Deng H, Richie JP Jr (2008) Inhibition of caspase-3 activity and activation by protein glutathionylation. Biochem Pharmacol 75: 2234 2244. 
114. Balazadeh S, Riaño-Pachón DM, Muller-Roeber B (2008) Transcription factors regulating leaf senescence in Arabidopsis thaliana. Plant Biol 10: 63-75.

115. Wagstaff C, Malcolm P, Rafiq A, Leverentz M, Griffiths G, et al. (2003) Programmed cell death (PCD) processes begin extremely early in Alstroemeria petal senescence. New Phytol 160: 49-59.

116. Pennell RI, Lamb C (1997) Programmed cell death in plants. Plant Cell 9: 1157-1168.

117. Reape TJ, McCabe PF (2008) Apoptotic-like programmed cell death in plants. New Phytol 180: 13-26.

118. Kranner I, Kastberger G, Hartbauer M, Pritchard HW (2010) Noninvasive diagnosis of seed viability using infrared thermography. P Natl Acad Sci USA 107: 3912-3917.
119. Schiebold S, Tschiersch H, Borisjuk L, Heinzel N, Radchuk R, et al. (2011) A novel procedure for the quantitative analysis of metabolites, storage products and transcripts of laser microdissected seed tissues of Brassica napus. Plant Methods 7: 19

120. El-Maarouf-Bouteau H, Mazuy C, Corbineau F, Bailly C (2011) DNA alteration and programmed cell death during ageing of sunflower seed. J Exp Bot 62: 5003-5011.

121. Osborne DJ, Boubriak I (2002) Telomeres and their relevance to the life and death of seeds. Crit Rev Plant Sci 21: 127-141. 